\title{
The Influence of Board Independence on Dividend Policy in Controlling Agency Problems in Family Firms*
}

\author{
Erhan Kilincarslan \\ University of Huddersfield \\ Department of Accounting, Finance and Economics \\ Queensgate, HD1 3DH \\ Huddersfield, UK \\ Email: e.kilincarslan@hud.ac.uk \\ Tel: +44 (0) 1484472810
}

Corresponding Author:

Erhan Kilincarslan

This research did not receive any specific grant from funding agencies in the public, commercial, or not-for-profit sectors.

Declarations of interest: None

*Forthcoming in "International Journal of Accounting and Information Management" - Accepted on 16 June 2021 


\title{
The Influence of Board Independence on Dividend Policy in Controlling Agency Problems in Family Firms
}

\begin{abstract}
Purpose - This study investigates the impact of board independence on the cash dividend payments of family firms listed on the Borsa Istanbul (BIST) in balancing controlling families' power to mitigate agency problems between family and minority shareholders in the post-2012 period. We focus on this period because Turkish authorities implemented mandatory regulations on the employment of independent directors on boards from fiscal year 2012.

Design/methodology/approach - The research model uses a panel dataset of 153 BIST-listed family firms over the period 2012-2017, employs alternative dependent variables and regression techniques, and is applied to various sub-groups to improve robustness.

Findings - The empirical results show a strong positive effect of board independence on dividend decisions. We further detect that family directorship exhibits a negative effect, whereas both board size and audit committees have positive influences but CEO/duality has had no significant impact on the dividend policies of Turkish family firms since the new compulsory legal requirements in the Turkish market.

Research implications - Our findings suggest that independent directorship and dividend policy are complementary governance mechanisms to reduce agency conflicts between families and minority shareholders in Turkey, which is a civil law-based emerging country characterized by high family ownership concentration.

Practical implications - We present evidence that Turkish family firms' corporate boards have evolved, to some extent, from being managerial rubber stamps to more independent boards that raise opposing voices in family decision making. However, independent directors' preference for dividend-induced capital market monitoring implies that their direct monitoring is less effective than it is supposed to be. This suggests a need to revise the Turkish Corporate Governance Principles to enhance independent directors' monitoring and supervisory power.

Originality value - This is thought to be the first study to provide insights on how board independence influences dividend policy in controlling agency problems in Turkish family firms since Turkish authorities introduced compulsory rules on the employment of independent directors on boards.
\end{abstract}

Keywords: Board independence, dividend policy, family firms, agency problem, Turkey.

Paper type: Research paper 


\section{Introduction}

Traditional agency-cost theory derives from problems associated with the separation of management and ownership in firms where ownership is dispersed among small shareholders but corporate control is concentrated in the hands of managers (Berle and Means, 1932; Jensen and Meckling, 1976; Easterbrook, 1984; Jensen, 1986). Yet conventional wisdom suggests that agency problems function differently in family-controlled companies. This is because families' direct involvement in managing their firms leads to closer supervision and fewer ownermanager conflicts (Fama and Jensen, 1983; La Porta et al., 1999; Ang et al., 2000). Nevertheless, it is broadly contended that family owners implement policies that benefit themselves at the expense of minority (small) shareholders (Shleifer and Vishny, 1997; Morck and Yeung, 2003; Anderson and Reeb, 2004; Villalonga and Amit, 2006). The key agency problem is thus families' expropriation of minority investors' wealth.

La Porta et al. (2000) suggest that in developed capital markets, corporate law generally provides potential investors and existing shareholders with legal powers to protect their wealth against expropriation. However, in countries with poor institutional settings and weak shareholders' rights, typically in emerging economies, they argue that cash dividends are a substitute for legal protection. By paying dividends, controlling shareholders (i.e., family owners) guarantee a pro rata cash distribution to all shareholders, which in turn reduces the possibility of expropriating wealth from others, and hence reduces conflicts of interest between controlling and minority owners. Since boards of directors make dividend policy decisions, their governance role is particularly crucial in alleviating agency problems between families and minority owners.

However, family firms' top executive positions and board seats are almost always provided to family members, and therefore their boards of directors are rarely independent of the controlling family (La Porta et al., 1999; Faccio et al., 2001; Yoshikawa and Rasheed, 2010). Hence, family directors/executives play an important role in either paying large dividends as a trust-generating device or distributing no (or low) dividends to retain cash that they can potentially expropriate. At this point, agency theory argues that independent directors may serve as an effective corporate governance mechanism in monitoring family directors' decisions and controlling their opportunistic behavior. This is due to their independence from corporate management and strong incentives to signal their directorial reputation and expertise to the market (Fama and Jensen, 1983; Westphal, 1998; Anderson and Reeb, 2004). It is therefore suggested that independent directors are in a better position to protect the interests of outside shareholders, especially in emerging markets where legislation provides insufficient protection for existing and potential minority investors.

Consequently, if independent directors have sufficient power to scrutinize and control family executives' actions, there is less need to pay cash dividends as an internal disciplinary device for corporate managers. This implies that board independence and dividend payments are substitute means of mitigating agency problems in family firms. Nevertheless, families generally tend not to appoint boards that might weaken their authority, and thus often seek to minimize independent director representation and/or effectiveness (Shleifer and Vishny, 1997; Anderson and Reeb, 2004; Setia-Atmaja et al., 2009). Thus, if independent directors believe 
their direct monitoring and supervision of management are ineffective, they may push for high dividend payouts to decrease internally available cash that might be manipulated by family managers to the detriment of outside shareholders. This suggests that independent directorship and dividend policy are complementary tools to curb such conflicts between family and minority owners.

The foregoing discussion clearly illustrates the important role of independent directors and their crucial impact on dividend policy in balancing controlling families' power and mitigating possible problems between family and minority shareholders in countries with poor legal protection. However, this issue remains underresearched. Previous studies (e.g., Schellenger et al., 1989; Bathala and Rao, 1995; Al-Najjar and Hussainey, 2009; Setia-Atmaja, 2010; Sharma, 2011) have examined the relationship between board independence and dividends mainly by considering traditional owner-manager conflict in Anglo-American capital markets, where companies usually have highly diffused ownership structures and rely on alternative governance devices (e.g., institutional investors, managerial incentives and takeover market) to reduce agency problems, but these are less practical in family firms. This study investigates whether board independence and cash dividends are substitutes or complementary in alleviating family-minority owner conflicts in family-controlled firms, and contributes new evidence from an emerging market to the business research literature from family-firm-setting.

We focus on Turkey, one of the most important emerging countries, strategically located between Europe and Asia and a candidate member of the European Union (EU). We use an agency-theory framework to examine family firms listed on the Borsa Istanbul (BIST). Turkey is a relevant setting for the study because the ownership structures of BIST-listed firms are highly concentrated, mainly dominated by families who own groups of companies and often use corporate pyramids, cross-shareholdings and dual-class shares to augment their control. Also, Turkish families generally seek to govern the boards in order to exert further control through board representation (Yurtoglu, 2003; Caliskan and Icke, 2011; Al-Najjar and Kilincarslan, 2016; 2017). In this setting, agency costs typically stem from conflicts between controlling families and minority shareholders. More importantly, Turkey's Capital Markets Board (CMB), its sole regulatory and supervisory authority for securities markets, published its Corporate Governance Principles in 2003, which made useful recommendations on board independence aimed at improving corporate governance practices. Previous studies show that there were formerly few independent directors on the boards of family-controlled corporations, and their boards often rubber stamped family owners' decisions (IIF, 2005; Oba et al., 2010; Ararat et al., 2010; Caliskan and Icke, 2011).

The CMB has constantly revised and amended its Principles (in 2005 and 2011) and in 2011 issued Communiqué Serial IV No. 56 on the Determination and Implementation of Corporate Governance Principles, which contained a new set of mandatory principles for BISTlisted firms. Through this Communiqué, the CMB converted voluntary directives into legal and compulsory regulations on board composition and the employment of independent members on boards. The mandatory Principles include (i) that boards of directors should comprise no fewer than five members, (ii) that boards must include independent members, (iii) that independent directors cannot comprise less than a third of the board, and (iv) that there must be at least two independent directors on the board (Nuhoglu and Erdogan, 2017). These developments enable 
us to study how board independence influences dividend policy in controlling agency problems in Turkish family firms.

We contribute to the family business literature by providing new evidence on the association between independent directorship and dividend payments in family-controlled firms, which may curb opportunistic behavior by family owners and prevent their expropriation of wealth from minority shareholders. Our evidence extends most previous findings in the owner-manager-related agency literature, and fills a gap in discussions of agency concerns by examining the unique characteristics of publicly-listed family firms beyond developed economies. Turkey is a civil law-based emerging country characterized by high family ownership concentration, with a history of poor governance and disclosure practices, and weaker shareholder protection than developed countries that have relatively dispersed ownership structures, more established governance systems and stronger investor protection legislation. Moreover, the implementation of mandatory regulations on employing independent directors may lead board members to take differing positions that exacerbate or mitigate conflicts between families and minority shareholders. Hence, we also examine relationships between other board characteristics (family member directorship, board size, CEO/chair duality and audit committee size) and dividend payment decisions in family business settings. This is thought to be the first study of this topic in Turkey since the CMB introduced compulsory rules on the employment of independent directors on boards.

In the remainder of this paper, Section 2 reviews the literature and develop research hypotheses within the agency framework. Section 3 describes the methodology and Section 4 presents the empirical results. Section 5 discusses the findings and draws some conclusions.

\section{Literature Review and Hypothesis Development}

Following Berle and Means's (1932) concept of the modern corporation, where ownership of capital is dispersed among small shareholders but control is concentrated in the hands of managers, traditional agency-cost theory stems from conflicts of interest between shareholders (the principal) and management (the agent). In the corporate dividend policy literature, numerous studies of principal-agent conflict (originally developed by Jensen and Meckling, 1976; Easterbrook, 1984; Jensen, 1986) suggest that cash dividend payments help minimize agency problems between managers and shareholders. Indeed, Easterbrook (1984) argues that paying large dividends reduces internal cash for discretionary use by managers, forcing them to raise external finance to meet the funding needs of new projects. The increase in costly outside capital induces more efficient monitoring by the capital market (i.e., outside professionals such as investment banks, lawyers, public accountants and potential investors), which assists in ensuring that managers perform in shareholders' best interests, and decreases the chance of sub-optimal investment. Similarly, it is suggested that shareholders seek generous dividend payments to reduce the amount of free cash that managers might use unprofitably, for instance by investing in negative NPV projects or unwise acquisitions (Jensen, 1986), or misuse for their own benefit (Jensen and Meckling, 1976).

However, various cross-country studies (e.g., Shleifer and Vishny, 1997; La Porta et al., 1999; Claessens et al., 2000; Faccio et al., 2001) document that concentrated ownership is the 
dominant ownership structure in most developing economies, in contrast to Berle and Means's (1932) image of the widely-held corporation. La Porta et al.'s (1999) investigation of the ownership structures of large firms in 27 countries reveals that most are heavily concentrated and family-controlled. Furthermore, Claessens et al. (2000) report that more than two-thirds of publicly listed East Asian firms are controlled by single shareholders, and families dominate about $40 \%$ of all listed companies. Faccio et al.'s (2001) examination of 5,897 companies from West European and East Asian countries indicates that family control is the dominant form of ownership in East Asia, and is even more common in Western Europe. According to Shleifer and Vishny (1997), family-owned firms govern the majority of developing economies in South America. Consequently, increasing evidence reveals that family firms are widespread, with growing economic importance globally.

\subsection{Family control and agency problems in family firms}

La Porta et al. (1999) argue that families are almost always involved in managing their firms. Since they are the controlling owners and managers, their direct involvement provides greater alignment between the interests of shareholders and managers. As a result, family control is one of the most efficient forms of organizational governance to monitor managers, providing more effective supervision and management. This in turn leads to no or fewer owner-manager agency problems in family-controlled firms than in corporations with highly dispersed ownership structures (Fama and Jensen, 1983; La Porta et al., 1999; Ang et al., 2000).

However, family control increases the moral hazard arising from abuse of control rights, and families may have powerful incentives to expropriate wealth from minority shareholders. Indeed, Shleifer and Vishny (1997) contend that when large shareholders, and especially family owners, hold almost full control, they tend to reap private benefits that are not shared with minority shareholders. Families can spend corporate funds and implement policies that benefit themselves, such as paying themselves high salaries, and giving top managerial positions and board seats to family members who may not be competent. Faccio et al. (2001) state that families are likely to expropriate wealth when their control rights are greater than their cash flow rights, and Villalonga and Amit (2006) suggest that families have greater incentives than other controlling shareholders to expropriate wealth from minority shareholders. Similarly, Anderson and Reeb (2004) emphasize that founding families may be involved in self-dealing by lessening firm risk, enriching themselves at the expense of minority owners, engaging in non-profit-maximizing projects, misusing firms' resources or generally prioritizing their interests over those of other investors. In such cases, the salient agency problem is conflict between controlling (principal) and minority (principal) shareholders. In particular, evidence from various studies indicates that principal-principal conflict is more prevalent in familycontrolled, publicly-listed firms. Daily et al. (2003) suggest that agency cost theory may function differently in such firms, and that previous findings from widely-held corporations may not be readily generalizable to this setting.

As discussed above, in most emerging economies, companies usually have controlling shareholders, typically founding families, who own significant proportions of equity. Although family ownership may lead to better governance in scrutinizing and controlling managers (La Porta et al., 1999), owing to a lack of effective monitoring on them, family shareholders (as 
insiders) have nevertheless increased access to and control over the use of corporate funds, which increases agency concerns between families and small shareholders. In fact, it is broadly contended that families have powerful motivations to expropriate wealth from minority shareholders (Shleifer and Vishny, 1997; Johnson et al., 2000; Morck and Yeung, 2003; Anderson and Reeb, 2004; Villalonga and Amit, 2006).

From the principal-principal conflict standpoint, family owners may use their controlling power to exacerbate minority owners' wealth in various ways. For instance, Morck and Yeung (2003) emphasize the "other people's money" problem, where families have significant control over a firm but invest very little in it. This occurs when cash flow and control rights are separated through pyramidal company structures or multiple classes of shares with different voting power. In such cases, controlling families may divert resources to themselves and, as previously mentioned, obtain the "private benefits of control" (Shleifer and Vishny, 1997). They may act only in their own interests, for example by lessening firm risk, enlarging their control at the cost of minority owners and misusing internal funds for non-profitable projects that benefit themselves. Moreover, Johnson et al. (2000) coin the term "tunneling", where controlling families transfer assets and profits from firms within a business group in which they lower higher ownership to firms with higher ownership. Tunneling may take many forms, including outright theft or fraud, more subtle legal forms such as dilutive share issues that discriminate against minority shareholders, and mergers between affiliated companies to transfer resources away from the bidder.

Johnson et al. (2000) assert that the expropriation threat is especially great in business groups. Examining group firms in India, which are often controlled by a single family through the ownership of equity shares, Bertrand et al. (2002) indeed report a significant amount of tunneling - much of it occurring via non-operating earnings items. Cheung et al. (2006) investigate a sample of connected transactions between companies listed on the Stock Exchange of Hong Kong in which two-thirds of publicly listed firms are dominated by a family who controls at least $20 \%$ of voting rights. They find direct evidence that minority shareholders experience significant value losses when companies undertake related party transactions. As an emerging country with a weak legal protection of minority shareholders, the Chinese capital market is also characterized by highly concentrated family businesses. Jiang et al. (2010) point out the nature and severity of the tunneling problem in China, and document that controlling shareholders expropriate corporate resources from minority investors to themselves, typically through the related party transactions and the misuse of company assets. In another study, Liu et al. (2015) analyze the relationship between family control and cash holding policy in China, and detect that family companies with excess control rights seem to have high cash holdings that are tunneled instead of being invested and/or distributed to shareholders. Given the longstanding tunneling behavior by the controlling families in the Chinese market, Gong et al. (2021) however suggest that controlling shareholders decrease the expropriation of minority shareholders under the monitoring of independent directors.

In short, the salient agency problem is the risk of controlling shareholder expropriation of minority investors in family-controlled firms - in other words, the principal-principal conflict, which may seriously harm the interests of minority shareholders. 


\subsection{Family firms and dividend policy}

La Porta et al. (2000) suggest that one of the main remedies to these types of agency problems is the law. Corporate law and the legal environment may provide outside shareholders and potential investors with powers to protect their wealth against expropriation by controlling shareholders. Although developed capital markets generally have effective legal environments and strong shareholder rights, most developing (emerging) economies have relatively poor institutional settings and weak shareholder rights. In this context, La Porta et al. (2000) argue that cash dividends substitute for legal protection for minority shareholders in countries with poor legal environments. This is because in paying dividends, controlling shareholders return profits to other shareholders, reduce the possibility of wealth expropriation and establish a reputation for treating minority shareholders well. In view of potential conflicts of interest between controlling family owners and minority investors, and given that dividend payments guarantee pro rata cash distributions to all shareholders, generous cash dividends undoubtedly minimize cash available for expropriation and help establish a reputation for treating minority shareholders in family-controlled firms well, especially in emerging markets.

Yet, it is difficult to judge whether families prefer to mitigate agency concerns through dividend payments or to expropriate wealth from minority shareholders by not distributing cash dividends. In developing markets, existing research provides mixed evidence on familycontrolled companies' dividend policy behavior. Studying companies from nine Eurozone countries, Pindado et al. (2012) show that family firms pay higher and more stable dividends, whereas Gugler's (2003) analysis of Austrian firms finds that family firms tend to distribute significantly lower dividends. However, Goergen et al. (2005) detect that family control in Germany has no significant effect on dividend payment decisions. Chen et al.'s (2005) investigation of Hong Kong firms shows that for small firms is there a significant negative association between dividend payouts and family ownership of up to $10 \%$ of the firm's shareholdings, but a positive relationship for family ownership between $10 \%$ and $35 \%$. They suggest that this is because dividend payments are intentionally avoided by controlling families in smaller Hong Kong companies to extract resources out of the firms they control. When their shareholdings increase, family managers care more about their dividend income than their cash salaries, because the latter are generally much lower. However, other shareholders may foresee potential expropriation by families and require higher payouts. Examining S\&P 500 firms, Hu et al. (2008) report that family firms have lower dividend payout ratios than non-family firms. In contrast, Setia-Atmaja et al. (2009) show that family control relates positively to dividend payments in Australia and Yoshikawa and Rasheed (2010) report similar results in Japan.

In Faccio et al.'s (2001) examination of firms from five West European and nine East Asian countries, family control is the predominant form of ownership in both regions, suggesting that the salient agency problem in these countries is expropriation of outside shareholders' wealth by family owners. Faccio et al. (2001) investigate the association between dividend payment decisions and firms' corporate control and ownership structure, and report that group-affiliated firms in Europe pay significantly higher cash dividends than their counterparts in Asia. In addition, they detect that the presence of multiple large shareholders increases dividend payout rates in West Europe but decreases them in East Asia, which indicates that other large owners seem to help reduce controlling shareholders' (typically, families') expropriation from minority 
owners in Europe, but appear to exacerbate it in Asia.

Indeed, most extant studies conducted in emerging markets with relatively low investor protection reveal a tendency for families to pay lower dividends. For example, Wei et al. (2011) identify that family companies have lower dividend payouts and a lower propensity to distribute cash dividends than non-family firms in China. Gonzalez et al. (2014) examine the effect of family involvement on dividend policy in Colombia. However, their results show that in relation to the level and likelihood of dividend payments, family influence differs considerably according to the type of family involvement: their involvement in management does not affect dividend policy, their involvement in both ownership and control through pyramids has a negative impact, and their involvement in control through disproportionate board representation has a positive effect on dividend policies. Al-Najjar and Kilincarslan (2016) report that family involvement (through both ownership and board representation) does not affect decisions on whether to pay dividends, but has a negative impact on dividend payouts in Turkey, while Setiawan et al. (2016) show that family firms pay lower dividends in Indonesia.

Consequently, although previous studies do not reach a consensus on the dividend practices of family-controlled firms and it is unclear whether families generally attempt to mitigate or exacerbate agency concerns through cash dividends, dividend policy is undoubtedly one of the most vital internal mechanisms for minimizing such concerns and helping establish a reputation for treating minority shareholders fairly.

\subsection{Family firms and board independence}

Since boards of directors make dividend payment decisions, the governance role of corporate boards is crucial to alleviating conflicts of interest between families and minority owners. However, another major way for families to exercise control is through board representation, and there is substantial evidence that top executive positions and boards seats are almost always allocated to family members in family-controlled corporations (La Porta et al., 1999; Faccio et al., 2001). In this respect, family board membership may reduce the boards' effectiveness as a monitoring mechanism owing to lack of independence. Therefore, family directors/executives play an important role in either paying large dividends as a trust-generating device or distributing no (or low) dividends to retain cash for potential expropriation.

So who monitors family directors' decisions? The answer may be independent nonexecutive directors on the board. Indeed, the agency-theory literature considers independent directors to be a useful mechanism for monitoring executive directors' actions, and thus reducing agency conflicts of interest within a firm (Jensen and Meckling, 1976; Jensen, 1993). Since governance tools in family firms are relatively limited, independent directors may provide effective governance by scrutinizing family directors' decisions and controlling their opportunistic behavior (Westphal, 1998; Anderson and Reeb, 2004), owing to their independence from corporate management and strong incentives to signal their directorial reputation and expertise to the market (Fama and Jensen, 1983). Therefore, they may be in a better position to protect the interests of outside shareholders, especially in emerging markets with insufficient legal protection for minority investors. Minority investors' interests are best protected when independent directors have power over family block holders. Hence, if 
independent directors have sufficient power to scrutinize and control family executives' actions, they will reduce the need to pay cash dividends as an internal disciplinary device over corporate managers. This implies that board independence and dividend payments are substitute means of mitigating agency problems in family firms.

Nevertheless, families generally tend not to appoint directors who may weaken their authority, and often seek to minimize independent director representation and/or effectiveness (Shleifer and Vishny, 1997; Anderson and Reeb, 2004; Setia-Atmaja et al., 2009). Therefore, if independent directors believe that their direct monitoring and supervision of management are ineffective, they may push for high dividend payouts to reduce the amount of internal cash at the family managers' discretion that may be manipulated to the detriment of outside shareholders. This suggests that independent directorship and dividend policy are complementary tools to curb such conflicts between family and minority owners.

The above discussion clearly illustrates independent directors' important role and their crucial impact on dividend policy to balance controlling families' power and mitigate problems between family and minority shareholders in countries with poor legal protection. We therefore investigate whether board independence and cash dividends are substitutes or complementary in alleviating family-minority owner conflicts in family-controlled firms, and contribute new evidence from an emerging market.

\subsection{Research context in Turkey and hypotheses}

Early studies reveal that historically, unlike the highly dispersed ownership structures in AngloAmerican capital markets, publicly listed firms in Turkey generally had high ownership concentration. Founding families, who usually owned business groups affiliated with industrial (businesses and subsidiaries) and financial (banks) companies organized under the legal form of a "holding company," dominated this concentrated ownership (Yurtoglu, 2003; Caliskan and Icke, 2011; Al-Najjar and Kilincarslan, 2016; 2017). The popularity of holding company structures led the Turkish financial system to operate around large family-controlled business groups with a group-owned bank. Moreover, controlling families often attempted to use pyramidal corporate structures or even more complicated webs of intercorporate equity linkages and dual-class shares to further strengthen their control at the expense of other shareholders, especially minority owners (Yurtoglu, 2003, IIF, 2005).

As a result of this infrastructure, and given Turkey's civil law tradition (with a poor culture of corporate governance, lack of transparency and disclosure and inconsistent accounting regulations), agency problems generally stemmed from the convergence of ownership and management, asymmetric information and weak minority shareholder and creditor rights. This created an environment of corruption, with share dilution, asset stripping, tunneling, insider trading and market manipulation (Ararat and Ugur, 2003; Aksu and Kosedag, 2006). The late 1990s saw a long list of public corruption scandals, most of which involved simple resource transfers (e.g., outright theft or fraud) by controlling shareholders from their firms, whose minority investors experienced huge losses (Yurtoglu, 2003). A number of well-publicized cases also showed that families had opportunities to expropriate profits using company assets or through non-arm's-length transactions at the expense of other owners. These events revealed 
that unfair treatment of minority shareholders by family owners was a serious corporate governance problem in Turkey (IIF, 2005).

The CMB however afforded great importance to improving communications with investors, issuers and other institutions to ensure that the markets would function in a safer, more transparent and more efficient manner in accordance with regulations harmonized with international norms and developments (CMB, 2003). In this respect, one of the most important developments, in cooperation with the World Bank and the Organisation for Economic Cooperation and Development (OECD), was the CMB's publication of its "Corporate Governance Principles" in 2003, which aimed to improve the corporate governance practices of firms listed on the stock exchange (CMB, 2003; Caliskan and Icke, 2011). According to the OECD (2006), these Principles contained comprehensive and high-quality governance practices reflecting the best international standards and practices in many areas.

When the Turkish stock exchange first started to operate in 1986, Turkish authorities imposed heavy mandatory dividend policy rules - known as the "first dividend" - on publicly listed firms. According to these rules, the listed firms had to pay at least $50 \%$ of their distributable profit as a cash dividend. Without paying the first dividend, all other dividend payments or maintaining it as retained earnings were not legally possible. This is in line with evidence that countries with poor legal environments and weak minority shareholders' protection, mostly emerging markets such as Brazil, Chile, Philippines and Venezuela, place minimum requirements on publicly listed firms' dividends to protect shareholders and creditors (La Porta et al., 2000; Aivazian et al., 2003). It is also consistent with La Porta et al.'s (2000) substitute model, which considers dividend payments to be a substitute for legal protection. In paying dividends, controlling shareholders return profits to all investors, thereby reducing the possibility of wealth expropriation and reassuring minority shareholders that they will not be (entirely) expropriated. Starting with fiscal year 1995, the CMB of Turkey however abolished the mandatory cash dividends distribution requirement which allowed the listed firms to decide between distributing dividends in any forms and keeping their profits as retained earnings (Adaoglu, 1999; 2000; Kirkulak and Kurt, 2010; Kilincarslan, 2015; Al-Najjar and Kilincarslan, 2016; 2018).

The CMB made important changes to the regulatory framework on dividend policy in early 2000s. In particular, it re-introduced mandatory dividend payments in 2003 , forcing listed Turkish firms to pay at least $20 \%$ of their distributable income as the first dividend - however, the requirements at this time were much more flexible as compared to the first regulation, since they did not have to pay this amount entirely in cash but had the option to distribute it in the form of cash or stock dividends or a mixture of the two. In fiscal year 2004, the CMB increased the minimum mandatory dividend payment from $20 \%$ to $30 \%$, and maintained it at this level in 2005. In 2006 it was reduced to $20 \%$, where it remained until the end of 2008. Nevertheless, from fiscal year 2009, the CMB abolished mandatory dividend regulations (CMB, 2003; 2004; 2006; 2009; Adaoglu, 2008; Kirkulak and Kurt, 2010; Kilincarslan, 2015; Al-Najjar and Kilincarslan, 2016; 2018; Baker and Kilincarslan, 2019). This action gave corporate managers the freedom to set their own dividend policy, which is subject to voting in their general assembly, with a requirement that any decisions on dividends must be publicly disclosed. Given that families almost always govern the boards and mostly hold the majority of shareholdings 
with greater voting rights in their general meetings; especially, Turkish publicly listed family firms enjoyed this freedom to pursue their dividend distribution policies or to decide against paying dividends and retaining earnings within the firm.

Turkey's serious efforts to implement major economic and structural reforms in the early 2000s have improved its market economy, enabling it to integrate with world markets, and have enhanced its corporate governance practices in many areas. However, the Turkish market is still heavily concentrated and characterized by family ownership (IIF, 2005; Caliskan and Icke, 2011; Al-Najjar and Kilincarslan, 2016; 2017; Baker et al, 2018). Thus, the abolition of compulsory dividend payouts has raised concerns because, as in many other emerging economies, top executive positions and board seats are usually occupied by Turkish family members (Yurtoglu, 2003; Caliskan and Icke, 2011; Al-Najjar and Kilincarslan, 2016). Since corporate boards of family firms are now allowed to choose whether or not to distribute dividends, they may prefer no or lower cash dividend payments to maintain internally generated cash flows for potential expropriation.

Accordingly, it is crucial to employ other governance mechanisms to monitor family activities, and thus control their opportunistic behavior. Extant studies suggest that various conventional governance tools (e.g., takeover threats, institutional block holders and managerial incentives) used to control owner-manager conflicts in highly dispersed firms are generally unlikely to be as effective in alleviating agency problems between family and minority shareholders in family-controlled firms (Shivdasani, 1993; Kole 1997; Setia-Atmaja, 2010). Hence, it is recommended that independent directors play a crucial role in scrutinizing and restricting possible opportunistic behavior by controlling families and mitigating wealth expropriation (Westphal, 1998; Faccio et al., 2001; Anderson and Reeb, 2004).

The CMB's Corporate Governance Principles emphasized the importance of boards of directors' independence to improve governance practices and strengthen the rights of the individual shareholders against controlling block holders (Ararat et al., 2010; Caliskan and Icke, 2011). However, acceptance and application of the Principles by Turkish listed firms was relatively slow since most were dominated by a single family as the controlling shareholder. Many, but no means all, family-owned firms tended to avoid implementing key governance provisions that might constrain family control, with very limited appointments of independent board members (IIF, 2005; Caliskan and Icke, 2011). For example, the OECD (2006) reported that only $17 \%$ of Turkish listed firms had independent directors in 2004. Ararat et al.'s (2010) dataset of boards of directors in Istanbul Stock Exchange 100 Index companies (944 directors in 2006 and 939 in 2008) reveals that only $7.53 \%$ were independent members in 2006, and $6.28 \%$ in 2008.

As is often the case in other family-dominated emerging markets, independent directors may be avoided because listed firms in Turkey generally tend not to require supermajorities, and are therefore unlikely to appoint boards that may limit their control over their firms' resources. Previous studies reveal that the boards of family-owned companies often largely rubber stamp decisions made by the families. In fact, although many family-controlled company boards have non-executive directors, they are likely to be a small minority and generally serve on the boards of subsidiaries, minimizing their influence as an efficient internal 
monitoring and discipline mechanism (IIF, 2005; Oba et al., 2010; Ararat et al., 2010; Caliskan and Icke, 2011; Kilincarslan, 2015; Al-Najjar and Kilincarslan, 2016).

Nevertheless, as previously mentioned, the CMB has constantly revised and amended its Principles, including converting them from voluntary directives to legal and compulsory rules, and requiring firms to comply by adapting their articles of association and restructuring their boards. The mandatory principles cover board composition and the employment of independent directors (Nuhoglu and Erdogan, 2017), enabling this study of how board independence influences dividend policy to control agency problems in family firms in an emerging market.

As previously discussed, if independent directors are effective monitors in scrutinizing family executives' and directors' activities and controlling their opportunistic behavior, they will reduce both moral hazard conflicts between families and minority shareholders, and the need to employ high cash dividends as an internal governance mechanism to prevent possible expropriation of corporate funds. On the one hand, considering the longstanding social culture and common corporate practices in the Turkish market, it is unrealistic to expect an immediate impact of the recent legal and regulatory reforms in strengthening independent directors' effectiveness in monitoring and controlling top managerial activities in family-dominated firms in Turkey. On the other hand, we conjecture that the serious efforts to provide a better legal and institutional setting and implement stringent rules and regulations have resulted in an environment in which independent directors no longer play a ceremonial role and simply rubber stamp controlling families' decisions. Rather, if they believe that their monitoring and supervision are ineffective, they will push for high dividend distributions to decrease internal cash available for potential manipulation by family managers to the detriment of outside shareholders. Thus, it is hypothesized that board independence and dividend payments are complementary tools to curb agency problems between family and minority owners:

Hypothesis 1: There is a positive relationship between board independence and cash dividend payment decisions in family firms in Turkey.

We also focus on relationships between other board characteristics (family directorship, board size, CEO/chair duality and audit committee size) and dividend payment decisions by Turkish family firms. This is because in closely-held family firms, the new regulations on the mandatory employment of independent directors may have led board members to take different positions in exacerbating or mitigating conflicts between families and minority shareholders.

In addition to concentrated family ownership, another common characteristic of Turkish firms is insider boards. Owner families govern the boards of Turkish listed firms, and the families generally use them as an internal control mechanism (Yurtoglu, 2003; Caliskan and Icke, 2011). Early studies conducted in Turkey (e.g., Yurtoglu, 2003) reported that at least half of board directors were also members of the owning family in family-controlled Turkish companies, and the IIF (2005) reported that $80 \%$ of listed companies in Turkey had at least one family board member and on average more than a third of board directors were members of the controlling family. Ararat et al. (2010) detect that around $18.34 \%$ of directors were members of the dominant family in 2006, and $17.86 \%$ in 2008 . More recently, using a panel dataset of financial firms listed on the Borsa Istanbul, Kilincarslan $(2017 ; 2018)$ reports the presence of 
at least one family member on the board on average, with boards comprising around eight executives, about $17.5 \%$ of whom are from owning families.

Although some aspects of family-owned firm structures may be advantageous in minimizing managerial agency problems in Turkey; family members' direct involvement easily influences managerial decisions, potentially offering opportunities for dominant families to expropriate profits from minority investors, typically by using company assets or through nonarm's-length transactions (IIF, 2005). As previously mentioned, during the late 1990s, listed firms' minority shareholders were harmed by the prevalence of corruption (Ararat and Ugur, 2003; Yurtoglu, 2003; IIF, 2005). Given the abolition of mandatory dividend payouts in 2009 has given corporate managers freedom to make their own dividend decisions and controlling families have strong incentives for expropriation, we therefore expect family directors to prefer to distribute no or lower dividends to keep cash flows within their discretion. This is because internally generated cash provides cheap and easily accessible funds to use for their own benefit at the expense of minority shareholders. Hence:

Hypothesis 2: There is a negative relationship between family directors and cash dividend payment decisions in family firms in Turkey.

The agency-cost theoretical framework suggests that boards of directors play a crucial monitoring and disciplinary role in executive management, and thus significantly reduce agency problems (Fama and Jensen, 1983; Weisbach, 1988; Jensen, 1993). Their role in limiting the power of controlling shareholders is especially important in countries with weak investor protection, where dominant shareholders such as families have greater ability and motivation to expropriate from minority owners (Westphal, 1998; Setia-Atmaja, 2010). There are two opposing views in the corporate governance literature regarding the effective number of board members. For example, Fiegener et al. (2000) and Gabrielsson (2007) contend that larger boards have greater expertise and diversity of specialization and can thus monitor more effectively, thereby reducing the monitoring role of dividend payments. In contrast, Jensen (1993) argues that it is more difficult to coordinate large groups of directors, whereas a small board with sufficient independent directors provides more effective monitoring. However, Dahya et al. (2008) highlight the importance of appointing a strong board to help curb dominant shareholders' diversion of corporate resources, especially in countries with weak legal protection for minority shareholders.

In Turkey, family firms have not normally appointed boards that might restrict their control over the firm's resources. Previous studies reveal that, historically, the boards of directors of Turkish family firms typically consisted of family members and executive directors, whereas very few employed independent board members (IIF, 2005; Oba et al., 2010; Ararat et al., 2010; Caliskan and Icke, 2011). Following the CMB's 2011 Communiqué, which enacted various compulsory legal requirements regarding board size and composition and the mandatory appointment of independent board members, we anticipate an increase in the size of boards of listed Turkish firms, but it is still questionable whether larger boards have brought more effective monitoring and supervision to family firms in the presence of such dominant shareholders. In fact, Al-Najjar and Kilincarslan (2016) and Kilincarslan (2018) find that board size has a positive impact on both the likelihood and intensity of dividend payment decisions 
by listed firms in Turkey. Hence, it is postulated that as a result of their weak monitoring role, larger boards will push for higher dividend payments to increase dividend-induced capital market monitoring in order to compensate for their poor monitoring. Thus:

Hypothesis 3: There is a positive relationship between board size and cash dividend payment decisions in family firms in Turkey.

When a firm's CEO chairs the board of directors, combining the two roles may be advantageous to the firm because it provides a strong and unified leadership with a clear direction and quicker decision making (Finkelstein and D'Aveni, 1994). However, according to agency theory, $\mathrm{CEO} /$ chair duality promotes the concentration of executive power in CEOs' hands, allowing them to exert more power over the board's decisions and practices in their own interests and at the expense of shareholders. This duality also weakens the board's independence since it reduces monitoring of the CEO, and the CEO's increased control and power may lead to the selection of less effective monitoring measures. For example, the CEO may deliberately choose to appoint more insiders and fewer independent members to the board (Fama and Jensen, 1983; Jensen, 1993; Hermalin and Weisbach, 1998; Booth et al., 2002). Separating the roles of CEO and chair has thus been strongly recommended (e.g., Cadbury Report and Sarbanes-Oxley Act).

Although some previous studies report no correlation between $\mathrm{CEO} /$ chair duality and dividends (e.g., $\mathrm{Hu}$ and Kumar, 2004; Elmagrhi et al., 2017), most find a negative effect of duality on dividend payout policies (e.g., Zhang, 2008; Chen et al., 2011; Litai et al., 2011; Sharma, 2011). Since controlling families often have strong motivations to implement policies that benefit themselves and expropriate wealth from minority shareholders (Shleifer and Vishny, 1997; Morck and Yeung, 2003; Anderson and Reeb, 2004; Villalonga and Amit, 2006), and top executive posts and board seats are typically occupied by family members (La Porta et al., 1999; Faccio et al., 2001; Yoshikawa and Rasheed, 2010), combining the CEO and chair roles is likely to negatively influence a board's ability to monitor management and control executives' opportunistic behavior in family firms. This raises serious agency concerns, as duality increases family control over resources and decisions, and thus leads to the payment of no or low dividends (Schulze et al., 2003; Braun and Sharma, 2007). Based on the above discussion, we therefore hypothesize that $\mathrm{CEO}$ /chair duality will have a negative impact on the dividend payments of listed firms in Turkey, where ownership and boards are dominated by families, with relatively weak legal protection for minority shareholders. Therefore:

Hypothesis 4: There is a negative relationship between CEO/chair duality and cash dividend payments decisions in family firms in Turkey.

It is suggested that monitoring should not be limited to the main board's composition, but should also extend to the board's sub-committees. For example, audit committees play a significant monitoring role to reduce agency costs (Kesner, 1988; Lorsch, 1995; Klein, 1998; Xie et al., 2003). When the CMB first published its Principles in 2003, the only legal requirement was for the formation of an audit committee (Ararat and Ugur, 2006). However, based on a sample of 118 listed Turkish firms over the period 2006-2008, Ararat et al. (2010) find that the majority of sampled firms did not disclose the names of audit committee members, 
even though all had had such committees since 2003. In distinguishing between "largely ceremonial" audit committees that do not disclose their members' names and "functional" committees that do, Ararat et al. (2010) find that only $27.6 \%$ of firms had "functional audit committees" in earlier periods in the Turkish market.

Nevertheless, the CMB's 2011 Communiqué implemented stringent rules on establishing audit committees, aiming to ensure that their duties and responsibilities are executed efficiently. Specifically, audit committees should be composed of at least two members; if they have two members, both should be independent directors, and if there are more than two, the majority should be independent directors; and the chair of the committee should be elected from among the board's independent members (Nuhoglu and Erdogan, 2017). Independent directors may help limit self-serving families and protect outside shareholders by imposing structural constraints on important board sub-committees, such as audit, investment, nomination and compensation committees (Shleifer and Vishny, 1997; Anderson and Reeb, 2004). There is little empirical evidence on the relationship between audit committee size and dividend policy. However, using a sample of small and medium-sized UK enterprises, Elmagrhi et al. (2017) show that audit committee size has a positive effect on dividend payments. In the Turkish setting, we thus postulate that larger audit committees will have more power than smaller ones to substitute their weak monitoring with dividend-induced capital market monitoring, encouraging family firms to pay higher dividends and hence reducing the funds available for expropriation. Therefore:

Hypothesis 5: There is a positive relationship between audit committee size and cash dividend payment decisions in family firms in Turkey.

\section{Methodology}

\subsection{Data sample}

Using the Borsa Istanbul's (2018) public disclosure platform, we identified 323 companies listed on the Borsa Istanbul All-Shares Index on April 1, 2018. Then, we excluded financialsector corporations and utilities, since they are governed by different regulations, have different capital structures and arguably follow different investment and dividend policies. These exclusions resulted in 227 industrial companies, of which 153 were family-controlled firms. We verified family firms by considering direct involvement (through ownership and board/executive participation) and connected relationships (i.e., family-owned holding companies controlled using pyramidal structures, cross-ownership and dual-class shares) of a single family or sometimes a few families. Next, we obtained accounting and financial data from Bureau van Dijk's Osiris database, cross-checked the validity of the data with Thomson Reuters' Datastream database, and compiled information on firm ownership and board structure from annual reports published on BIST's public disclosure platform and firms' official websites. The final sample consisted of a panel dataset of 918 firm-year observations of 153 unique BIST-listed family firms from 14 broad industries between 2012 and 2017.

\subsection{Research design, models and variables}

We computed logit and Tobit regression models to test our research hypotheses. This is because 
we used two different dividend policy measures (i.e., two different dependent variables), and the type of dependent variable defines the appropriate econometric technique. First, we formulated a logit model to estimate a binary dependent variable (Model 1), since firms have the option of either paying or not paying dividends $(0 / 1)$ in deciding their dividend policy (the probability of paying dividends). Second, we estimated the intensity of paying cash dividends using the dividend payout ratio. A firm's dividend payout ratio will never be negative (leftcensored at zero) and may have two outcomes: either zero (a discrete number) if the firm does not pay dividends, or a positive value (continuous values) if the firm pays dividends. Hence, we designed a Tobit model to estimate this dependent variable (Model 2).

We outlined a set of test variables proxying for the five research hypotheses and various control variables, based on those most commonly used in related literature. In addition, because the research sample was drawn from 14 different industries and covered a relatively long period (2012-2017), we included industry and year dummies in the models to control for industryspecific effects and unobserved time-varying factors. Finally, to alleviate endogeneity concerns, we used one-year lagged values for all independent variables (except industry and year dummies) to ensure that they were predetermined with respect to the dividend payment decision. The corresponding logit and Tobit models are constructed as follows:
Model 1: Logit $\left(\right.$ DIVPAY $\left._{i, t}\right)=\alpha+\beta_{1}$ INDEPENDENCY $_{i, t-1}+\beta_{2}$ FAMBOARD $_{i, t-1}+$ $\beta_{3}$ BOARDSIZE $_{i, t-1}+\beta_{4}$ DUALITY $_{i, t-1}+\beta_{5}$ AUDIT $_{i, t-1}+\beta_{6}$ ROA $_{i, t-1}+$ $\beta_{7}$ LEVERAGE $_{i, t-1}+\beta_{8}$ GROWTH $_{i, t-1}+\beta_{9}$ FIRMSIZE $_{i, t-1}+$ $\beta_{10}$ BLOCKOWN $_{i, t-1}+\sum_{j=1}^{N} \beta_{j}$ INDUSTRY $_{j, i, t}+\sum_{t=1}^{T} \beta_{t}$ YEAR $_{i, t}+\varepsilon$,

Model 2: Tobit $\left(\right.$ DIVRATIO $\left._{i, t}\right)=\delta+\gamma_{1}$ INDEPENDENCY $_{i, t-1}+\gamma_{2}$ FAMBOARD $_{i, t-1}+$ $\gamma_{3}$ BOARDSIZE $_{i, t-1}+\gamma_{4}$ DUALITY $_{i, t-1}+\gamma_{5}$ AUDIT $_{i, t-1}+\gamma_{6}$ ROA $_{i, t-1}+$ $\gamma_{7}$ LEVERAGE $_{i, t-1}+\gamma_{8}$ GROWTH $_{i, t-1}+\gamma_{9}$ FIRMSIZE $_{i, t-1}+$ $\gamma_{10}$ BLOCKOWN $_{i, t-1}+\sum_{j=1}^{N} \gamma_{j} \operatorname{INDUSTRY}_{j, i, t}+\sum_{t=1}^{T} \gamma_{t} \mathrm{YEAR}_{i, t}+\omega$

where DIVPAY is the probability of paying a cash dividend, which is a binary code $(0 / 1)$ that equals 1 if the firm distributes dividends and 0 otherwise (Model 1), and DIVRATIO is the dividend payout ratio (Model 2). The test variables are as follows: INDEPENDENCY is board independence, FAMBOARD is family directorship, BOARDSIZE is the total number of directors on the board, DUALITY is CEO/chair duality and AUDIT is the audit committee size. With respect to the control variables, ROA is the return on assets (profitability), LEVERAGE is the debt level, GROWTH is the market-to-book ratio (growth/investment opportunities), FIRMSIZE is the firm size, BLOCKOWN is a dummy variable representing the presence of other large shareholders such as foreign and national investors which equals 1 if such blockholders exist and 0 otherwise, INDUSTRY is a vector of dummy variables for 14 different industry classifications, and YEAR is a year dummy for each year between 2012 and 2017, taking a value of 1 for the particular year and 0 otherwise. Detailed definitions of all variables used in the models are shown in Table 1.

(Insert Table 1 about here) 


\section{Empirical Results}

\subsection{Descriptive analysis}

Panel A of Table 2 presents descriptive statistics for our research variables, collected from a panel dataset of 153 BIST-listed industrial family firms with 918 firm-year observations over the period 2012-2017. The mean DIVPAY (0.412) shows that BIST family firms paid cash dividends in about $41 \%$ of total observations, and DIVRATIO indicates a ratio of cash dividends paid to total assets of $1.9 \%$. The results also reveal that the board size (BOARDSIZE) of sampled firms varied from five to 15 members, with an average of seven directors. The average proportions of independent directors and family members on boards were approximately 32\% (INDEPENDENCY) and 31\% (FAMBOARD), respectively. CEOs also chaired the boards in almost $37 \%$ of observations (DUALITY), and audit committees (AUDIT) generally comprised two directors (with a median of 2, a minimum of 1 and a maximum of 6). Regarding other firm-specific characteristics, firms had about $24 \%$ debt financing in their capital structures (LEVERAGE), and around a $4.2 \%$ return on their total assets invested over the period 2012-2017 (ROA). On average, BIST family firms showed good growth prospects, since the mean market-to-book ratio of 1.468 (GROW) is higher than unity. In addition, in approximately $28 \%$ of total observations, the sampled firms had other large shareholders (i.e., foreign and national investor stockholdings captured at the 5\% threshold ownership level) rather than controlling families over the research period (BLOCKOWN).

Panel B of Table 2 reports Pearson's correlation and variance inflation factor (VIF) results for the independent variables to check for multicollinearity. Despite some significant correlations among the research variables, there is no high correlation between any two of them, and a few are moderately correlated. For instance, the highest Pearson's correlation figures, for INDEPENDENCY-BOARDSIZE, FAMBOARD-DUALITY and BOARDSIZE-FIRMSIZE, range from $47 \%$ to $51 \%$. As a rule of thumb, a VIF greater than 10 and a tolerance (1/VIF) value lower than 0.1 indicate multicollinearity (Gujarati, 2003; Al-Najjar and Kilincarslan, 2016; Ko et al., 2019; AlHares et al., 2020; Kilincarslan et al., 2020; Chiang et al., 2021). Given that all VIF values are comparatively low (ranging from 1.13 to 2.23) and all tolerance values are higher than 0.1 , our results suggest no multicollinearity between the independent variables.

(Insert Table 2 about here)

\subsection{Regression analysis}

We computed our logit and Tobit models by applying pooled and random effects (panel) regression estimates. This was done to determine whether pooled or panel regression techniques were more favorable for estimating our models, thus providing more reliable and robust results. We also calculated the marginal effects (economic significance) of the explanatory variables to obtain further interpretations in addition to the coefficient estimates (statistical significance). These show the marginal impact of each explanatory variable on the dependent variable at the mean values of other explanatory variables. Panel A of Table 3 illustrates the results of the pooled and random effects logit estimations (Model 1), and Panel B of Table 3 presents the results of the pooled and random effects Tobit estimations (Model 2).

(Insert Table 3 about here) 
The results indicate that when Models 1 and 2 are estimated using pooled logit and Tobit regressions, they are both statistically significant overall at the $1 \%$ level, as evidenced by Wald $\chi^{2}$ and $F$ tests, respectively. When using random effects (panel) regressions, the overall significance of both models is also highly significant at the $1 \%$ level, as reported by Wald $\chi^{2}$ tests. Therefore, we examined the likelihood-ratio tests, which were statistically significant for both models at the $1 \%$ level, showing that the panel-level variance $(\rho)$ values differed considerably from zero ( 0.697 for Model 1 and 0.535 for Model 2). These findings suggest that the random effects estimates are more favorable than the pooled estimates for our models. Hence, we report the empirical findings based on the former, although we detect very similar results using pooled logit and Tobit regression for both models.

The random effects logit estimates shown in Panel A reveal a strong positive effect of board independence on the probability of paying a cash dividend. The coefficient for INDEPENDENCY $\left(\beta_{1}=0.679, p<0.01\right)$ is positive and statistically significant at the $1 \%$ level.

The marginal effect of this variable means that, all else being equal, a percentage-point increase in board independence will increase the likelihood of paying dividends by about $5.7 \%$. The random effects Tobit estimates in Panel B also indicate a highly significant positive impact of board independence on the dividend payout ratio $\left(\gamma_{1}=0.154, p<0.01\right)$. The marginal effect of INDEPENDENCY indicates that an average firm's dividend payout will increase by approximately $4.2 \%$ with a percentage-point increase in board independence. This evidence of a positive relationship is in line with previous studies (e.g., Schellenger et al., 1989; SetiaAtmaja, 2010; Sharma, 2011), and suggests that independent directors encourage BIST-listed family firms to pay cash dividends to increase dividend-induced capital market monitoring. This implies that board independence and dividends are complementary mechanisms to reduce agency problems between family and minority shareholders, lending support for Hypothesis 1 .

On the other hand, the random effects logit (Panel A) and Tobit (Panel B) estimates show a solid negative effect of family board directorship on dividend decisions, as the coefficients of FAMBOARD are negative and statistically significant $\left(\beta_{2}=-0.152, p<0.05\right.$ in Model $1 ; \gamma_{2}=$ $-0.0304, p<0.05$ in Model 2). The marginal effects of this variable, other things being equal, demonstrate that a percentage-point increase in the proportion of family directors on the board decreases the probability of paying a cash dividend by about $4 \%$ and the level of dividend payout ratio by about $0.73 \%$ for an average family firm. This negative association is consistent with the notion that families have powerful motivations to expropriate wealth from minority owners (Shleifer and Vishny, 1997; Morck and Yeung, 2003; Anderson and Reeb, 2004; Villalonga and Amit, 2006), and implies that family directorships in Turkey are likely to exacerbate wealth expropriation by influencing boards to distribute no or lower dividends. This supports Hypothesis 2.

The results in Tables 3 reveal another strong positive relationship between board size and dividend policy. The coefficients for BOARDSIZE are statistically significant and positive in the logit and Tobit regressions $\left(\beta_{3}=0.210, p<0.05\right.$ in Model $1 ; \gamma_{3}=0.0045, p<0.01$ in Model 2 ). The marginal effects of this variable show that the probability of paying a cash dividend increases by about $4.5 \%$ and the dividend payout ratio rises by around $1.2 \%$ with a one-unit increase in board size. These findings accord with Al-Najjar and Kilincarslan's (2016) and 
Kilincarslan's (2018) studies conducted in Turkey, and with other studies (e.g., Kiel and Nicholson, 2003; Litai et al., 2011; Elmagrhi et al., 2017). They suggest that larger boards encourage Turkish family firms to distribute higher dividends to compensate for their poor monitoring, providing support for Hypothesis 3.

The random effects logit and Tobit estimates show no significant association between $\mathrm{CEO} /$ chair duality and dividend payment decisions by BIST family firms at any conventional significance levels. This evidence of an insignificant relationship is consistent with prior studies (e.g., Hu and Kumar, 2004; Elmagrhi et al., 2017) and leads to rejection of Hypothesis 4.

The results in Tables 3 further report that the random effects coefficients for AUDIT are positive and statistically significant at the $10 \%$ level in the logit model and at the $1 \%$ level in the Tobit model $\left(\beta_{5}=0.160, p<0.10\right.$ in Model $1 ; \gamma_{5}=0.0197, p<0.01$ in Model 2). The marginal effects of this variable indicate that a one-unit increase in audit committee size increases the likelihood of paying cash dividends by about $2.6 \%$ and the dividend payout ratio by around $0.54 \%$ on average. The positive association between audit committee size and dividend policy is in line with Elmagrhi et al. (2017), and suggests that larger audit committees tend to have more power to substitute their weak monitoring by encouraging family firms to reduce the cash available for expropriation. This evidence provides support for Hypothesis 5.

Finally, Tables 3 shows that five control variables are robustly significant in both models. The results indicate that profitability (ROA) and firm size (FIRMSIZE) have positive effects, and the use of debt (LEVERAGE), growth/investment opportunities (GROWTH) and other large shareholders (BLOCKOWN) have negative impacts on dividend decisions. These results suggest that more profitable and larger family firms are more likely to pay dividends (and distribute higher dividends), whereas family firms with more debt, higher growth opportunities and the presence of other large shareholders are less likely to pay dividends (and distribute lower dividends) in the Turkish market.

\subsection{Further analysis}

We performed additional tests to check the robustness of our main findings. In particular, we computed the logit model (Model 1) and Tobit model (Model 2) on various sub-samples based on the five firm characteristics (control variables) that were found to be statistically significant in the models. In doing so, we attempted to provide more robust findings and assess the consistency of the main findings across different dimensions. We stratified our sample into (1) high- and low-profitability firms, (2) firms with high and low leverage, (3) high- and lowgrowth firms, (4) large and small firms, and (5) the presence or absence of other types of blockholders. Tables 4 and 5 illustrate the results of the random effects logit (Models 1A-1E) and Tobit (Models 2A-2E) estimations for the 10 sub-samples based on the five firm characteristics. These results are consistent because the test variables have the same directional signs and exhibit similar statistical significance. Overall, this evidence confirms the robustness of our main findings.

(Insert Table 4 about here)

(Insert Table 5 about here) 


\section{Discussion and Conclusions}

This study examines the impact of board independence on dividend policy in family firms listed on the Borsa Istanbul in mitigating agency problems between controlling families and minority shareholders. We focus on the post-2012 period because the Turkish authorities implemented mandatory regulations on the employment of independent directors on boards from fiscal year 2012. Given that Turkish families had almost always dominated corporate boards and were extremely reluctant to appoint independent directors who might limit their control and activities as a result of the longstanding social culture and common corporate practices, this presented an opportunity to investigate, using an agency-theory-framework, the effect of changing power dynamics in the boardrooms of family-owned firms resulting from this legal enforcement on corporate dividend decisions.

This study makes an important contribution to the business research literature, providing new evidence on how board independence is associated with dividend policy in curbing opportunistic behavior by controlling family owners to prevent wealth expropriation in the Turkish setting. Turkey is an emerging country with a civil law system, characterized by a high family ownership concentration, a history of poor governance and disclosure practices, and weaker shareholder protection than developed countries with relatively dispersed ownership structures, more established governance systems and stronger investor protection legislation. Thus, our evidence goes beyond the findings of most previous owner-manager agency literature, and fills a gap in research on agency concerns relating to the unique characteristics of publicly listed family firms outside developed economies.

Several important conclusions can be drawn from this study. Specifically, our empirical results show that board independence has a strong positive impact, whereas family directorship exhibits a consistently negative effect on the dividend policies of Turkish family firms. Furthermore, both board size and audit committees have positive influences, but CEO/chair duality has had no significant effect on the dividend payment decisions of family-dominated companies since the reforms and developments in the Turkish market.

As predicted, there is consistent evidence of an inverse correlation between family involvement through board representation and dividend payments. This negative relationship may be attributable to the convergence of ownership and management owing to family members' direct participation, which increases internal monitoring, thus reducing traditional agency concerns between managers and owners, and in turn mitigating the need to pay cash dividends to alleviate such concerns. However, the wealth expropriation argument based on principal-principal conflict is that when family owners hold almost full control, they tend to extract private benefits from corporate resources at the expense of minority shareholders. In this context, agency concerns between controlling families and other shareholders (especially minority investors) are more prevalent in family-dominated firms in Turkey. Therefore, a more likely explanation for the negative relationship between family directorship and dividends is that family owners prefer no or lower cash dividends in order to preserve internal cash for potential expropriation. Other possible interpretations of families' tendency to pay no or lower dividends include a willingness to use corporate funds for profitable growth/investment opportunities and/or to cater to shareholders who prefer capital gains over cash dividends. 
Nevertheless, our results reveal a strong positive impact of board independence on Turkish family firms' dividend payment decisions, which supports the wealth expropriation argument: if families' reason for distributing low dividends is either profitable investment projects or their shareholders' preferences, then independent directors will be more likely to approve their decisions rather than pushing them to pay higher dividends.

As previously discussed, historically, the boards of Turkish listed family firms were typically formed of family members and executive directors. Non-executive directors were generally appointed from those serving on the boards of subsidiaries, with few or no independent directors. This led to an environment in which the boards of family-controlled companies were far from independent and often played a ceremonial role, acting mostly as managerial rubber stamps for families' decisions. Reflecting the CMB's legal enforcements, in contrast to family directorship, the significant positive impact of board independence on dividend decisions suggests that independent directors now raise opposing opinions and force family firms to distribute cash in the form of dividends.

However, this positive influence contradicts the notion that independent directors may prevent wealth expropriation by monitoring family executives' activities, hence reducing the need for cash dividends. Rather, it implies that independent directors push for higher dividend payouts because their direct monitoring and supervision are ineffective. This is because a generous cash dividend distribution (i) reduces the amount of internal cash in family managers' control and pays it to all shareholders, thus, reducing what is left for expropriation; (ii) increases dividend-induced capital market monitoring; and (iii) establishes a trust-generating device for companies and a good directorial reputation to alleviate minority shareholders' expropriation concerns. Overall, we conclude that independent directorship and dividend policies are complementary mechanisms to control such conflicts in family firms in Turkey. In addition, the regulations on the mandatory appointment of independent board members and audit committees have positive effects on dividends. This indicates that larger boards and audit committees have more power to compensate for weak monitoring in family firms with dividend-induced monitoring, which also supports our conclusion.

Good corporate governance in a globalized economy is very important for companies, financial institutions and markets, and governments. Compliance with sound corporate governance helps increase confidence in and the credibility of publicly-listed corporations, thus improving a country's image. High-quality corporate governance attracts more foreign direct investment, prevents outflows of domestic capital and increases the competitive power of the economy and capital markets. In this respect, it is widely accepted that board independence is a vital element in implementing, improving and maintaining the quality of firms' corporate governance practices. Also, independent directors play an essential role in protecting shareholders' rights, and especially the interests of minority shareholders.

Our results have important practical implications for policymakers, corporate managers and investors. First, we present evidence that Turkish family firms' corporate boards have evolved, to some extent, from being managerial rubber stamps to more independent boards that raise opposing voices in family decision making. However, independent directors' preference for dividend-induced capital market monitoring implies that their direct monitoring is less 
effective than it is supposed to be. This suggests a need to revise the CMB's Corporate Governance Principles to enhance independent directors' monitoring and supervisory power.

Second, good corporate governance is a key criterion that international investors look at almost exclusively when selecting companies in which to invest. Given that the ratio of stock owned by foreign investors to total stocks traded on the BIST is very high, ranging from $62 \%$ to $66 \%$ between 2012 and 2017 (CMB, 2016; 2017), family owners might consider creating an environment that enables independent directors to take a more active role, not only in setting strategies and endorsing legal and ethical visibility, but also in control. This would positively affect the company profile by indicating confidence to the market, and would hence attract more investment from both foreign and domestic investors, meaning more capital and liquidity, increased financial capabilities and better growth prospects.

Third, our results provide useful information to investors seeking to invest in the Turkish market. Since different types of investors and portfolio managers have differing preferences regarding returns on their investments (e.g., some desire dividend income, whereas others favor capital gains, or a mixture of both), they should carefully consider Turkish family firms' board composition prior to investing. Hence, knowledge of the association between independent directors and dividend policy in controlling the risk of expropriation may assist investors and portfolio managers in selecting companies with policies that best fit their investment targets.

Our study has several limitations. First, we focused only on cash dividend payments although share repurchases may serve another important way of cash distribution to shareholders. This is because our sampled Turkish family firms made limited use of share repurchases in very few occasions during the research period. Considering recent developments of regulatory changes of payout policies (including both dividends and share buybacks) in Turkey, it is however worth investigating whether share repurchases can now be alternative for cash dividends, and if so examining how independent directors react to approvals of share repurchase programs in family-controlled firms could be a subject of future study. Second, we hand-collected information on family directors, tracing through their surnames. Had we considered marital and other kinships, the true extent of family control over boards might have been greater. Third, our sample was limited to industrial family firms; hence, further research to extend the sample, for example to financial family firms, might provide a more complete picture of the relationship between board independence and dividends from the agency-theory view of such firms. Fourth, our study focused only on Turkish family firms publicly listed on the Borsa Istanbul. Given that family-dominated firms are predominant worldwide, and especially in most emerging economies, we strongly encourage comparative studies in other countries to determine the generalizability of our findings. Finally, the quantitative approach employed in this research may not provide in-depth insights into the association between independent board directorship and dividend policy in preventing expropriation in familyowned firms. Therefore, future studies might adopt a qualitative approach (e.g., case studies and interviews) to improve understanding in this area. Nevertheless, our findings and limitations provide a valuable benchmark for future studies of family businesses. 


\section{References}

Adaoglu, C. (1999). Regulation influence on the dividend policy of the Istanbul Stock Exchange (ISE) corporations, The Istanbul Stock Exchange (ISE) Review - Quarterly Economics and Finance Review, 3(11): 1-19.

Adaoglu, C. (2000). Instability in the dividend policy of the Istanbul Stock Exchange (ISE) corporations: evidence from an emerging market, Emerging Markets Review, 1(3): 252-270.

Adaoglu, C. (2008). Dividend policy of the ISE industrial corporations: the evidence revisited (1986-2007), Journal of BRSA Banking and Financial Markets, 2(2): 113-135.

Aivazian, V., Booth, L., \& Cleary, S. (2003). Dividend policy and the organisation of capital markets, Journal of Multinational Financial Management, 13(2): 101-121.

Aksu, M., \& Kosedag, A. (2006). Transparency and disclosure scores and their determinants in the Istanbul stock exchange, Corporate Governance: An International Review, 14(4): 277-296.

AlHares, A., Elamer, A. A., Alshbili, I., \& M. W. Moustafa (2020). Board structure and corporate R\&D intensity: evidence from Forbes global 2000, International Journal of Accounting and Information Management, 28(3): 445-463.

Al-Najjar, B., \& Hussainey, K. (2009). The association between dividend payout and outside directorships, Journal of Applied Accounting Research, 10(1): 4-19.

Al-Najjar, B., \& Kilincarslan, E. (2016). The effect of ownership structure on dividend policy: evidence from Turkey, Corporate Governance, 16(1): 135-161.

Al-Najjar, B., \& Kilincarslan, E. (2017). Corporate dividend decisions and dividend smoothing: new evidence from an empirical study of Turkish firms, International Journal of Managerial Finance, 13(3): 304-331.

Al-Najjar, B., \& Kilincarslan, E. (2018). Revisiting firm-specific determinants of dividend policy: evidence from Turkey, Economic Issues, 23(1): 3.-34.

Anderson, R.C., \& Reeb, D.M. (2004). Board composition: balancing family influence in S\&P 500 firms, Administrative Science Quarterly, 49(2): 209-237.

Ang, J.S., Cole, R.A., \& Lin, J.W. (2000). Agency costs and ownership structure, Journal of Finance, 55(1): 81-106.

Ararat, M., \& Ugur, M. (2003). Corporate governance in Turkey: an overview and some policy recommendations, Corporate Governance, 3(1): 58-75.

Ararat, M., \& Ugur, M. (2006). Does macroeconomic performance affect corporate governance? Evidence from Turkey, Corporate Governance, 14(4): 325-348.

Ararat, M., Orbay, H., \& Yurtoglu, B.B. (2010). The effects of board independence in controlled firms: evidence from Turkey, available at SSRN: https://ssrn.com/abstract $=1663403$

Baker, H.K., \& Kilincarslan, E. (2019). Why companies do not pay cash dividends: the Turkish experience, Global Finance Journal, 42(2019): 100419

Baker, H.K., Kilincarslan, E., \& Arsal, A.H. (2018). Dividend policy in Turkey: survey evidence from Borsa Istanbul firms, Global Finance Journal, 35: 43-57.

Bathala, C.T., \& Rao, R.P. (1995). The determinants of board composition: an agency theory perspective, Managerial and Decision Economics, 16(1): 59-69.

Berle, A., \& Means, G. (1932). The modern corporation and private property. New York, NY: MacMillan Press.

Bertrand, M., Mehta, P., \& Mullainathan, S. (2002). Ferreting out tunneling: an application to Indian business groups, Quarterly Journal of Economics, 117(1): 121-148.

Booth, J.R., Cornett, M.M., \& Tehranian, H. (2002). Boards of directors, ownership, and regulation, Journal of Banking and Finance, 26: 1973-1996.

Braun, M., \& Sharma, A. (2007). Should the CEO also be chair of the board? An empirical examination of family-controlled public firms, Family Business Review, 20(2): 111-126. 
Caliskan, N., \& Icke, T. (2011). Turkish corporate governance principles and its implications for ISE corporate governance index companies, Journal of Accounting and Finance, 11(1): 60-75.

Chen, L., Lin, C., \& Kim, Y.C. (2011). Financial characteristics, corporate governance and the propensity to pay cash dividends of Chinese listed companies, International Business and Management, 3(1): 176-188.

Chen, Z., Cheung, Y-L., Stouraitis, A., \& Wong, A.W.S. (2005). Ownership concentration, firm performance, and dividend policy in Hong Kong, Pacific-Basin Finance Journal, 13(4): 431449.

Cheung, Y-L., Rau, P.R., \& Stouraitis, A. (2006). Tunneling, propping, and expropriation: evidence from connected party transactions in Hong Kong, Journal of Financial Economics, 82: 343-386.

Chiang, S., Kleinman, G., \& Lee, P. (2021). The effect of auditor industry specialization and board independence on the cash flow reporting classification choices under IFRS: evidence from Taiwan, International Journal of Accounting \& Information Management, 29(1): 147168.

Claessens, S., Djankov, S. \&, Lang, L.H.P. (2000). The separation of ownership and control in East Asian corporations, Journal of Financial Economics, 58(1): 81-112.

CMB (2003). Annual report 2003. Ankara: Capital Markets Board of Turkey.

CMB (2004). Annual report 2004. Ankara: Capital Markets Board of Turkey.

CMB (2006). Annual report 2006. Ankara: Capital Markets Board of Turkey.

CMB (2009). Annual report 2009. Ankara: Capital Markets Board of Turkey.

CMB (2016). Annual report 2016. Ankara: Capital Markets Board of Turkey.

CMB (2017). Annual report 2017. Ankara: Capital Markets Board of Turkey.

Dahya, J., Dimitrov, O., \& McConnell, J.J. (2008). Dominant shareholders, corporate boards, and corporate value: a cross-country analysis, Journal of Financial Economics, 87: 73-100.

Daily, C.M., Dalton, D.R., \& Rajagopalan, N. (2003). Governance through ownership: centuries of practice, decades of research, Academy of Management Journal, 46(2): 151-158.

Easterbrook, F.H. (1984). Two agency-cost explanations of dividends, American Economic Review, 74(4): 650-659.

Elmagrhi, M.H., Ntim, C.G., Crossley, R.M., Malagila, J.K., Fosu, S., \& Vu, T.V. (2017). Corporate governance and dividend pay-out policy in UK listed SMEs: the effects of corporate board characteristics, International Journal of Accounting and Information Management, 25(4): 459-483.

Faccio, M., Lang, L.H.P., \& Young, L. (2001). Dividends and expropriation, American Economic Review, 91(1): 54-78.

Fama, E.F., \& Jensen, M.C. (1983). Separation of ownership and control, Journal of Law and Economics, 26(2): 301-325.

Fiegener, M.K., Brown, B.M., Dreux, D.R., \& Dennis, W.J. (2000). The adoption of outside boards by small private US firms, Entrepreneurship and Regional Development, 12: 291-309.

Finkelstein, S., \& D'Aveni, R.A. (1994). CEO duality as a double-edged sword: how board of directors balance entrenchment avoidance and unity of command, Academy of Management Journal, 37(5): 1079-1108.

Gabrielsson, J. (2007). Correlates of board empowerment in small companies, Entrepreneurship Theory and Practice, 31: 687-711.

Goergen, M., Renneboog, L., \& Correia da Silva, L. (2005). When do German firms change their dividends?, Journal of Corporate Finance, 11(1/2): 375-399.

Gong, M., Wang, Y., \& Yang, X. (2021). Do independent directors restrain controlling shareholders' tunneling? Evidence from a natural experiment in China, Economic Modelling, 94: 548-559.

Gonzalez, M., Guzman, A., Pombo, C., \& Trujillo, M-A. (2014). Family involvement and dividend policy in closely held firms, Family Business Review, 27(4): 365-385. 
Gugler, K. (2003). Corporate governance, dividend payout policy, and the interrelation between dividends, R\&D, and capital investment, Journal of Banking and Finance, 27(7): 1297-1321. Gujarati, D.N. (2003), Basic Econometrics, 4th ed., McGraw-Hill, New York, NY

Hermalin, B.E., \& Weisbach, M.S. (1998). Endogenously chosen boards of directors and their monitoring of the CEO, American Economic Review, 88(1): 96-118.

$\mathrm{Hu}$, A., \& Kumar, P. (2004). Managerial entrenchment and pay-out policy, Journal of Financial and Quantitative Analysis, 39(4): 759-790.

$\mathrm{Hu}$, Y., Wang, D., \& Zhang, S. (2008). Founding family ownership, management and payout policy, International Review of Business Research Papers, 3(2): 49-98.

IIF. (2005). Corporate governance in Turkey - an investor perspective, Task Force Report April 2005. Washington, DC: Institute of International Finance.

Jensen, M.C. (1986). Agency costs of free cash flow, corporate finance and takeovers, American Economic Review, 76(2): 323-329.

Jensen, M.C. (1993). The modern industrial revolution, exit and failure of internal control systems, Journal of Finance, 48(3): 831-880.

Jensen, M.C., \& Meckling, W.H. (1976). Theory of the firm: managerial behaviour, agency costs and ownership structure, Journal of Financial Economics, 3(4): 305-360.

Jiang, G., Lee, C.M.C. \& Yue, H. (2010). Tunneling through intercorporate loans: The China experience, Journal of Financial Economics, 98: 1-20.

Kesner, I.F. (1988). Directors' characteristics and committee membership: an investigation of type, occupation, tenure, and gender, Academy of Management Journal, 31(1): 66-84.

Kiel, G.C., \& Nicholson, G.J. (2003). Board composition and corporate performance: how the Australian experience informs contrasting theories of corporate governance, Corporate Governance: An International Review, 11(3): 189-205.

Kilincarslan, E. (2015). Dividend policy: evidence from Turkey, PhD thesis, London: Birkbeck, University of London.

Kilincarslan, E. (2017). Cash dividend payments: a study of financial sector in Turkey, Bankacılık ve Sigortacılık Araştırmaları Dergisi, 2(11): 92-117.

Kilincarslan, E. (2018). The factors determining the dividend policy of financial firms listed on the Borsa Istanbul, Bogazici Journal Review of Social, Economic and Administrative Studies, 32(1): 75-109.

Kilincarslan, E., Elmagrhi, M.H., \& Li, Z. (2020). Impact of governance structures on environmental disclosures in the Middle East and Africa, Corporate Governance: The International Journal of Business in Society, 20(4): 739-763.

Kirkulak, B. \& Kurt, G. (2010). Are dividends disappearing or shrinking? Evidence from the Istanbul Stock Exchange, Emerging Markets Finance and Trade, 46(2): 38-52.

Klein, A. (1998). Firm performance and board committee structure, Journal of Law and Economics, 41(1): 275-304.

Ko, C., Lee, P., \& A. Anandarajan (2019). The impact of operational risk incidents and moderating influence of corporate governance on credit risk and firm performance, International Journal of Accounting and Information Management, 27(1): 96-110.

Kole, S. (1997). The complexity of compensation contracts, Journal of Financial Economics, 43(1): 79-104.

La Porta, R., Lopez-de-Silanes, F., \& Shleifer, A. (1999). Corporate ownership around the world, Journal of Finance, 54(2): 471-517.

La Porta, R., Lopez-de-Silanes, F., Shleifer, A., \& Vishny, R.W. (2000). Agency problems and dividend policies around the world, Journal of Finance, 55(1): 1-33.

Litai, C., Chuan, L., \& Kim, Y. (2011). Financial characteristics, corporate governance and the propensity to pay cash dividends of Chinese listed companies, International Business and Management, 3(1): 176-188. 
Liu, Q., Luo, T., \& Tian, G.G. (2015). Family control and corporate cash holdings: evidence from China, Journal of Corporate Finance, 31: 220-245.

Lorsch, J.W. (1995). Empowering the board, Harvard Business Review, 73(1): 107-117.

Morck, R., \& Yeung, B. (2003). Agency problems in large family business groups, Entrepreneurship Theory and Practice, 27(4): 367-382.

Nuhoglu, I, \& Erdogan, S. (2017). The rise of "independent board members" in Turkey, Muhasebe and Finansman Dergisi, 73: 249-272.

Oba, B., Ozsoy, Z., \& Atakan, S. (2010). Power in the boardroom: a study on Turkish familyowned and listed companies, Corporate Governance, 10(5): 603-616.

OECD. (2006). Corporate governance in Turkey: a pilot study. Paris: OECD Publishing.

Pindado, J., Requejo, I., \& de la Torre, C. (2012). Do family firms use dividend policy as a governance mechanism? Evidence from the Euro zone, Corporate Governance: An International Review, 20(5): 413-431.

Schellenger, M., Wood, D., \& Tashakori, A. (1989). Board of director composition, shareholder wealth, and dividend policy, Journal of Management, 15(3): 457-67.

Setia-Atmaja, L. (2010). Dividend and debt policies of family controlled firms: the impact of board independence, International of Journal of Managerial Finance, 6(2): 128-142.

Setia-Atmaja, L., Tanewski, G.A., \& Skully, M. (2009). The role of dividends, debt and board structure in the governance of family controlled firms, Journal of Business Finance and Accounting, 36(7): 863-898.

Setiawan, D., Bandi, B., Phua, L.K., \& Trinugroho, I. (2016). Ownership structure and dividend policy in Indonesia, Journal of Asia Business Studies, 10(3): 230-252.

Sharma, V. (2011). Independent directors and the propensity to pay dividends, Journal of Corporate Finance, 17(4): 1001-1015.

Shivdasani, A. (1993). Board composition, ownership structure and hostile takeovers, Journal of Accounting and Economics, 16(1-3): 167-198.

Shleifer, A., \& Vishny, R.W. (1997). A survey of corporate governance, Journal of Finance, 52(2): 737-783.

Schulze, W.S., Lubatkin, M.H., \& Dino, R.N. (2003). Toward a theory of agency and altruism in family firms, Journal of Business Venturing, 18(4): 473-490.

Villalonga, B., \& Amit, R. (2006). How do family ownership, control and management affect firm value?, Journal of Financial Economics, 80(2): 385-417.

Wei, Z., Wu, S., Li, C., \& Chen, W. (2011). Family control, institutional environment and cash dividend policy: evidence from China, China Journal of Accounting Research, 4(1-2): 29-46.

Weisbach, M.S. (1988). Outside directors and CEO turnover, Journal of Financial Economics, 20(1-2): 431-460.

Westphal, J.D. (1998). Board games: how CEOs adapt to increases in structural board independence from management, Administrative Science Quarterly, 43(3): 511-538.

Xie, B., Davidson, W., \& DaDalt, P.J. (2003). Earnings management and corporate governance: the role of the board and the audit committee, Journal of Corporate Finance, 9(3): 295-316.

Yoshikawa, T., \& Rasheed, A.A. (2010). Family control and ownership monitoring in family controlled firms in Japan, Journal of Management Studies, 47(20): 274-295.

Yurtoglu, B.B. (2003). Corporate governance and implications for minority shareholders in Turkey, Journal of Corporate Ownership and Control, 1(1): 72-86.

Zhang, H. (2008). Corporate governance and dividend policy: a comparison of Chinese firms listed in Hong Kong and in the mainland, China Economic Review, 19(3): 437-459. 
Table 1. Research variables and definitions

Variable

\section{Dependent variables}

Probability of paying a cash dividend

Dividend payout ratio

Test variables

Board independence

Family board presentation

Board size

CEO/Chair duality

Audit committee size

\section{Control variables}

Return on assets

Debt level

Firm growth/investment opportunities

Firm size

Presence of other large shareholders

Industry effect

Time effect

\section{Abbreviation Definition}

DIVPAY Binary variable that equals 1 if the firm pays cash dividends and 0 otherwise

DIVRATIO Fraction of total cash dividends paid to total assets.

\section{INDEPENDENCY Fraction of independent directors to board size.}

FAMBOARD Fraction of family directors to board size.

BOARDSIZE Total number of directors on the board.

DUALITY Binary variable that equals 1 if the CEO is also the chairperson, and 0 otherwise.

AUDIT Total number of directors who serve on the audit committee.

ROA Ratio of net earnings to total assets.

LEVERAGE Ratio of total debt to total assets.

GROWTH Market-to-book value ratio.

FIRMSIZE Natural log of retail price index-adjusted annualised market value.

BLOCKOWN Binary variable that equals 1 if other large shareholders such foreign and/or national investors exist (at $5 \%$ threshold ownership level) within the family firm, and 0 otherwise.

Industry dummies representing 14 different industry classifications.

INDUSTRY

YEAR
Yearly dummies for the years between 2012 and 2017, which take a value of 1 for the particular year and 0 otherwise. 
Table 2. Descriptive statistics, Pearson's correlations and VIF values

Panel A: Descriptive statistics for the research variables

\begin{tabular}{|c|c|c|c|c|c|c|c|c|c|c|c|c|c|}
\hline Variables & DIVPAY & DIVRATIO & INDEPENDENCY & \multicolumn{2}{|c|}{ FAMBOARD } & BOARDSIZE & DUALITY & AUDIT & ROA & LEVERAGE & GROWTH & FIRMSIZE & BLOCKOWN \\
\hline Mean & 0.412 & 0.019 & 0.319 & \multicolumn{2}{|c|}{0.306} & 7.200 & 0.368 & 2.081 & 0.042 & 0.237 & 1.468 & 5.448 & 0.279 \\
\hline Median & 0.000 & 0.000 & 0.333 & \multicolumn{2}{|c|}{0.286} & 7.000 & 0.000 & 2.000 & 0.035 & 0.223 & 1.155 & 5.206 & 0.000 \\
\hline Std. Dev. & 0.492 & 0.038 & 0.073 & \multicolumn{2}{|c|}{2.068} & 2.077 & 0.482 & 0.393 & 0.099 & 0.195 & 1.064 & 1.785 & 0.448 \\
\hline Minimum & 0.000 & 0.000 & 0.133 & \multicolumn{2}{|c|}{0.000} & 5.000 & 0.000 & 1.000 & -0.386 & 0.000 & 0.343 & 1.604 & 0.000 \\
\hline Maximum & 1.000 & 0.372 & 0.667 & \multicolumn{2}{|c|}{0.778} & 15.000 & 1.000 & 6.000 & 0.995 & 0.929 & 10.129 & 10.129 & 1.000 \\
\hline Observations & 918 & 918 & 918 & \multicolumn{2}{|c|}{918} & 918 & 918 & 918 & 918 & 918 & 918 & 918 & 918 \\
\hline \multicolumn{14}{|c|}{ Panel B: Pearson's correlations and VIF values for the independent variables } \\
\hline \multicolumn{2}{|l|}{ Variables } & (1) & (2) & (3) & (4) & $(5)$ & $(6)$ & (7) & $(8)$ & (9) & $(10)$ & VIF & $1 / \mathrm{VIF}$ \\
\hline \multicolumn{2}{|c|}{ (1) INDEPENDENCY } & 1.000 & & & & & & & & & & 1.82 & 0.549 \\
\hline \multicolumn{2}{|c|}{ (2) FAMBOARD } & $0.106 * *$ & 1.000 & & & & & & & & & $1 / 42$ & 0.704 \\
\hline \multicolumn{2}{|c|}{ (3) BOARDSIZE } & $-0.507 * *$ & $-0.241 * *$ & 1.000 & & & & & & & & 2.23 & 0.448 \\
\hline \multicolumn{2}{|c|}{ (4) DUALITY } & $0.212 * *$ & $0.468 * *$ & $-0.206^{* *}$ & 1.000 & & & & & & & 1.38 & 0.725 \\
\hline \multicolumn{2}{|c|}{ (5) AUDIT } & $0.187 * *$ & $-0.073 *$ & $0.122 * *$ & 0.068 & 1.000 & & & & & & 1.17 & 0.855 \\
\hline \multicolumn{2}{|c|}{ (6) $\mathrm{ROA}$} & $0.099 * *$ & -0.039 & 0.085 & -0.063 & -0.010 & 1.000 & & & & & 1.33 & 0.752 \\
\hline \multicolumn{2}{|c|}{ (7) LEVERAGE } & $-0.069 *$ & $0.127 * *$ & $0.100 * *$ & $0.114 * *$ & -0.041 & $-0.355^{* *}$ & 1.000 & & & & 1.23 & 0.813 \\
\hline \multicolumn{2}{|c|}{ (8) GROWTH } & 0.029 & -0.046 & -0.013 & 0.018 & -0.007 & $0.273 * *$ & $-0.153 * *$ & 1.000 & & & 1.20 & 0.833 \\
\hline \multicolumn{2}{|c|}{ (9) FIRMSIZE } & $-0.233 * *$ & $-0.323 * *$ & $0.486 * *$ & $-0.240 * *$ & $0.144 * *$ & $0.296 * *$ & -0.035 & $0.299 * *$ & 1.000 & & 1.71 & 0.585 \\
\hline \multicolumn{2}{|c|}{ (10) BLOCKOWN } & $-0.222 * *$ & $-0.189 * *$ & $0.287 * *$ & $-0.128 * *$ & 0.064 & $0.086 * *$ & 0.056 & 0.063 & $0.228 * *$ & 1.000 & 1.13 & 0.885 \\
\hline
\end{tabular}

Notes: $* *$ and $*$ indicate significance at the $1 \%$ and $5 \%$ levels, respectively. The definitions of all variables are provided in Table 1. 
Table 3. Results of Logit and Tobit Models Estimates

\begin{tabular}{|c|c|c|c|c|c|c|c|c|}
\hline & \multicolumn{4}{|c|}{ PANEL A: Logit Estimates (Model 1) } & \multicolumn{4}{|c|}{ PANEL B: Tobit Estimates (Model 2) } \\
\hline \multirow{3}{*}{$\begin{array}{l}\text { Dependent variable: } \\
\text { Independent variables }\end{array}$} & \multicolumn{4}{|c|}{$\operatorname{DIVPAY}_{i, t}(0 / 1)$} & \multicolumn{4}{|c|}{ DIVRATIO $_{i, t}$} \\
\hline & \multicolumn{2}{|c|}{ Pooled Logit } & \multicolumn{2}{|c|}{ Random Effects Logit } & \multicolumn{2}{|c|}{ Pooled Tobit } & \multicolumn{2}{|c|}{ Random Effects Tobit } \\
\hline & $\begin{array}{c}\text { Coefficient } \\
\text { estimates }\end{array}$ & $\begin{array}{c}\text { Marginal } \\
\text { effects }\end{array}$ & $\begin{array}{c}\text { Coefficient } \\
\text { estimates }\end{array}$ & $\begin{array}{c}\text { Marginal } \\
\text { effects }\end{array}$ & $\begin{array}{c}\text { Coefficient } \\
\text { estimates }\end{array}$ & $\begin{array}{c}\text { Marginal } \\
\text { effects }\end{array}$ & $\begin{array}{c}\text { Coefficient } \\
\text { estimates }\end{array}$ & $\begin{array}{c}\text { Marginal } \\
\text { effects }\end{array}$ \\
\hline \multicolumn{9}{|l|}{ Test variables } \\
\hline INDEPENDENCY $_{i, t-1}$ & $\begin{array}{l}0.455 * * * \\
(3.35)\end{array}$ & $\begin{array}{l}0.053 * * * \\
(3.17)\end{array}$ & $\begin{array}{l}0.679 * * * \\
(3.11)\end{array}$ & $\begin{array}{l}0.057 * * * \\
(2.91)\end{array}$ & $\begin{array}{c}0.147 * * * \\
(3.26)\end{array}$ & $\begin{array}{l}0.0406 * * * \\
(3.59)\end{array}$ & $\begin{array}{l}0.154 * * * \\
(3.24)\end{array}$ & $\begin{array}{l}0.0417 * * * \\
\quad(3.55)\end{array}$ \\
\hline FAMBOARD $_{i, t-1}$ & $\begin{array}{c}-0.268 * * \\
(-2.10)\end{array}$ & $\begin{array}{c}-0.049 * * \\
(-2.31)\end{array}$ & $\begin{array}{c}-0.152 * * \\
(-2.25)\end{array}$ & $\begin{array}{c}-0.040 * * \\
(-2.36)\end{array}$ & $\begin{array}{c}-0.0314 * * \\
(-2.36)\end{array}$ & $\begin{array}{c}-0.0086 * * \\
(-2.41)\end{array}$ & $\begin{array}{c}-0.0304 * * \\
(-2.03)\end{array}$ & $\begin{array}{c}-0.0073 * * \\
(-2.09)\end{array}$ \\
\hline BOARDSIZE $_{i, t-1}$ & $\begin{array}{c}0.184 * * \\
(2.38)\end{array}$ & $\begin{array}{c}0.042 * * \\
(2.46)\end{array}$ & $\begin{array}{c}0.210^{* * *} \\
(2.29)\end{array}$ & $\begin{array}{c}0.045^{* *} \\
(2.41)\end{array}$ & $\begin{array}{c}0.0049 * * * \\
(2.87)\end{array}$ & $\begin{array}{c}0.0133 * * * \\
(3.50)\end{array}$ & $\begin{array}{c}0.0045^{* * * *} \\
(3.02)\end{array}$ & $\begin{array}{c}0.0121 * * * \\
(3.43)\end{array}$ \\
\hline DUALITY $_{i, t-1}$ & $\begin{array}{l}-0.357 \\
(-1.18)\end{array}$ & $\begin{array}{l}-0.074 \\
(-1.10)\end{array}$ & $\begin{array}{l}-0.496 \\
(-1.07)\end{array}$ & $\begin{array}{l}-0.056 \\
(-0.92)\end{array}$ & $\begin{array}{c}-0.0430 \\
(-0.86)\end{array}$ & $\begin{array}{c}-0.00118 \\
(-0.85)\end{array}$ & $\begin{array}{r}-0.0694 \\
(-1.12)\end{array}$ & $\begin{array}{c}-0.00123 \\
(-1.12)\end{array}$ \\
\hline AUDIT $_{i, t-1}$ & $\begin{array}{l}0.103^{*} \\
(1.85)\end{array}$ & $\begin{array}{l}0.023^{*} \\
(1.89)\end{array}$ & $\begin{array}{l}0.160^{*} \\
(1.84)\end{array}$ & $\begin{array}{l}0.026^{*} \\
(1.90)\end{array}$ & $\begin{array}{c}0.0209 * * * \\
(3.94)\end{array}$ & $\begin{array}{c}0.0057 * * * \\
(4.17)\end{array}$ & $\begin{array}{c}0.0197 * * * \\
\quad(4.04)\end{array}$ & $\begin{array}{c}0.0054 * * * \\
(4.29)\end{array}$ \\
\hline \multicolumn{9}{|l|}{ Control variables } \\
\hline $\mathrm{ROA}_{i, t-1}$ & $\begin{array}{c}12.117 * * * \\
(4.70)\end{array}$ & $\begin{array}{c}1.772 * * * \\
(4.59)\end{array}$ & $\begin{array}{c}9.751 * * * \\
(2.89)\end{array}$ & $\begin{array}{c}1.088 * * * \\
(2.87)\end{array}$ & $\begin{array}{c}0.434 * * * \\
(7.34)\end{array}$ & $\begin{array}{c}0.119 * * * \\
(8.09)\end{array}$ & $\begin{array}{c}0.405^{* * *} \\
(7.88)\end{array}$ & $\begin{array}{c}0.105^{* * * *} \\
(9.01)\end{array}$ \\
\hline LEVERAGE $_{i, t-1}$ & $\begin{array}{c}-2.918 * * * \\
(-3.75)\end{array}$ & $\begin{array}{c}-0.423 * * * \\
(-3.71)\end{array}$ & $\begin{array}{c}-2.376 * * * \\
(-3.09)\end{array}$ & $\begin{array}{c}-0.415 * * * \\
(-3.30)\end{array}$ & $\begin{array}{c}-0.0504 * * * \\
(-3.75)\end{array}$ & $\begin{array}{c}-0.0138 * * * \\
(-3.66)\end{array}$ & $\begin{array}{c}-0.0613 * * * \\
(-3.14)\end{array}$ & $\begin{array}{c}-0.0167 * * * \\
(-3.07)\end{array}$ \\
\hline GROWTH $_{i, t-1}$ & $\begin{array}{c}-0.463 * * \\
(-2.49)\end{array}$ & $\begin{array}{c}-0.141 * * \\
(-2.55)\end{array}$ & $\begin{array}{c}-0.337 * * \\
(-2.40)\end{array}$ & $\begin{array}{c}-0.127 * * \\
(-2.45)\end{array}$ & $\begin{array}{c}-0.00268 * * \\
(-2.10)\end{array}$ & $\begin{array}{c}-0.00153 * * \\
(-2.18)\end{array}$ & $\begin{array}{c}-0.00261^{* *} \\
(-2.22)\end{array}$ & $\begin{array}{c}-0.00149 * * \\
(-2.31)\end{array}$ \\
\hline FIRMSIZE $_{i, t-1}$ & $\begin{array}{c}0.909 * * * \\
(7.59)\end{array}$ & $\begin{array}{c}0.215 * * * \\
(8.04)\end{array}$ & $\begin{array}{c}0.783 * * * \\
(5.24)\end{array}$ & $\begin{array}{c}0.201 * * * \\
(6.86)\end{array}$ & $\begin{array}{c}0.0125 * * * \\
(6.98)\end{array}$ & $\begin{array}{c}0.0035 * * * \\
(7.35)\end{array}$ & $\begin{array}{c}0.0143 * * * \\
(5.06)\end{array}$ & $\begin{array}{c}0.0039 * * * \\
(5.11)\end{array}$ \\
\hline BLOCKOWN $_{i, t-1}$ & $\begin{array}{c}-0.753 * * \\
(-2.14)\end{array}$ & $\begin{array}{c}-0.188 * * \\
(-2.29)\end{array}$ & $\begin{array}{c}-0.855^{* *} \\
(-2.33)\end{array}$ & $\begin{array}{c}-0.175 * * \\
(-2.53)\end{array}$ & $\begin{array}{c}-0.0237 * * * \\
(-3.64)\end{array}$ & $\begin{array}{c}-0.0026 * * * \\
(-3.78)\end{array}$ & $\begin{array}{c}-0.0199 * * * \\
(-2.60)\end{array}$ & $\begin{array}{c}-0.0020 * * * \\
(-2.69)\end{array}$ \\
\hline INDUSTRY & Yes & Yes & Yes & Yes & Yes & Yes & Yes & Yes \\
\hline YEAR & Yes & Yes & Yes & Yes & Yes & Yes & Yes & Yes \\
\hline Constant & $\begin{array}{c}-7.005 * * * \\
(-5.07)\end{array}$ & & $\begin{array}{c}-8.234 * * * \\
(-6.53)\end{array}$ & & $\begin{array}{c}-0.126 * * * \\
(-3.82)\end{array}$ & & $\begin{array}{c}-0.131 * * * \\
(-3.44)\end{array}$ & \\
\hline Number of observations & 765 & 765 & 765 & 765 & 765 & 765 & 765 & 765 \\
\hline Wald $\chi^{2}$ & $176.12 * * *$ & & $59.63 * * *$ & & & & $218.24 * * *$ & \\
\hline F test & & & & & $10.03 * * *$ & & & \\
\hline Pseudo $R^{2}(\%)$ & $43.54 \%$ & & & & $23.69 \%$ & & & \\
\hline$\rho$ value & & & 0.697 & & & & 0.535 & \\
\hline Likelihood ratio test & & & $89.58 * * *$ & & & & $75.67 * * *$ & \\
\hline
\end{tabular}

Notes: This table reports the estimated logit/Tobit coefficients and marginal effects, and $t / z$-statistics in the parentheses. The pooled models are tested using White's corrected Notes: This table reports the estimated logit/Tobit coefficients and marginal effects, and $t / z$-statistics in the parentheses. The pooled models are tested using
heteroscedasticity robust regressions. Independent variables are one-year lagged. $* * *, * *$ and $*$ stand for significance at the $1 \%, 5 \%$ and $10 \%$ levels, respectively. 
Table 4. Results of Random Effects Logit Model Estimates by Firm Characteristics

\begin{tabular}{|c|c|c|c|c|c|c|c|c|c|c|}
\hline \multirow{2}{*}{$\begin{array}{l}\text { Models: } \\
\text { Independent variables: }\end{array}$} & \multicolumn{2}{|c|}{$\begin{array}{c}\text { PANEL A: Profitability } \\
\text { Model 1A }\end{array}$} & \multicolumn{2}{|c|}{$\begin{array}{c}\text { PANEL B: Leverage } \\
\text { Model 1B }\end{array}$} & \multicolumn{2}{|c|}{$\begin{array}{c}\text { PANEL C: Growth } \\
\text { Model 1C } \\
\end{array}$} & \multicolumn{2}{|c|}{$\begin{array}{c}\text { PANEL D: Firm size } \\
\text { Model 1D } \\
\end{array}$} & \multicolumn{2}{|c|}{$\begin{array}{c}\text { PANEL E: Blockholder(s) } \\
\text { Model 1E } \\
\end{array}$} \\
\hline & High & Low & High & Low & High & Low & Large & Small & Existed & Not existed \\
\hline \multicolumn{11}{|l|}{$\begin{array}{l}\text { Test variables } \\
\text { INDEPENDENCY }\end{array}$} \\
\hline $\begin{array}{l}\text { Coefficient estimates } \\
\text { Marginal effects }\end{array}$ & $\begin{array}{l}1.131 * * *(4.16) \\
0.064 * * *(3.30)\end{array}$ & $\begin{array}{l}0.560 * * *(3.61) \\
0.033 * * *(2.96)\end{array}$ & $\begin{array}{l}0.534 * * * *(2.87) \\
0.036^{* * * *}(2.61)\end{array}$ & $\begin{array}{l}1.461 * * *(3.10) \\
0.059 * * *(2.80)\end{array}$ & $\begin{array}{l}0.522 * *(2.32) \\
0.045^{* *}(1.99)\end{array}$ & $\begin{array}{l}0.757 * * *(3.28) \\
0.068 * * *(3.15)\end{array}$ & $\begin{array}{l}1.355^{* * *}(3.09) \\
0.072 * * *(2.91)\end{array}$ & $\begin{array}{l}0.549 * * *(2.85) \\
0.048 * * *(2.63)\end{array}$ & $\begin{array}{l}0.862 * * *(5.79) \\
0.061 * * *(5.05)\end{array}$ & $\begin{array}{l}0.681 * * *(3.93) \\
0.054 * * *(3.11)\end{array}$ \\
\hline \multicolumn{11}{|l|}{ FAMBOARD $_{i, t-1}$} \\
\hline $\begin{array}{l}\text { Coefficient estimates } \\
\text { Marginal effects }\end{array}$ & $\begin{array}{l}-0.119 * *(-2.40) \\
-0.028 * *(-2.48)\end{array}$ & $\begin{array}{l}-0.239^{* * *}(-2.81) \\
-0.055^{* * *}(-3.19)\end{array}$ & $\begin{array}{l}-0.328 * *(-2.45) \\
-0.057 * *(-2.53)\end{array}$ & $\begin{array}{l}-0.203 * *(-2.25) \\
-0.027 * *(-2.43)\end{array}$ & $\begin{array}{l}-0.228 * *(-2.03) \\
-0.054 * *(-2.29)\end{array}$ & $\begin{array}{l}-0.140 *(-1.85) \\
-0.032 *(-1.95)\end{array}$ & $\begin{array}{l}-0.166 * *(-2.10) \\
-0.038 * *(-2.26)\end{array}$ & $\begin{array}{l}-0.294 * *(-2.27) \\
-0.061 * *(-2.41)\end{array}$ & $\begin{array}{l}-0.170^{* *}(-2.33) \\
-0.050^{* *}(-2.40)\end{array}$ & $\begin{array}{l}-0.263^{* *}(-2.24) \\
-0.064 * *(-2.45)\end{array}$ \\
\hline \multicolumn{11}{|l|}{ BOARDSIZE $_{i, t-1}$} \\
\hline $\begin{array}{l}\text { Coefficient estimates } \\
\text { Marginal effects }\end{array}$ & $\begin{array}{l}0.445 * * *(3.29) \\
0.054 * * *(3.58)\end{array}$ & $\begin{array}{l}0.142 * *(2.31) \\
0.018^{* *}(2.52)\end{array}$ & $\begin{array}{l}0.349 * *(2.14) \\
0.023 * *(2.35)\end{array}$ & $\begin{array}{l}0.541 * *(2.22) \\
0.052 * *(2.41)\end{array}$ & $\begin{array}{l}0.188 * *(2.11) \\
0.040 * *(2.29)\end{array}$ & $\begin{array}{l}0.459 * *(2.32) \\
0.065 * *(2.50)\end{array}$ & $\begin{array}{l}0.560^{* *}(2.44) \\
0.059^{* *}(2.55)\end{array}$ & $\begin{array}{l}0.138^{* *}(2.16) \\
0.028 * *(2.25)\end{array}$ & $\begin{array}{l}0.201 * *(1.99) \\
0.043 * *(2.15)\end{array}$ & $\begin{array}{l}0.423 * *(2.30) \\
0.057 * *(2.51)\end{array}$ \\
\hline \multicolumn{11}{|l|}{ DUALITY $_{i, t-1}$} \\
\hline $\begin{array}{l}\text { Coefficient estimates } \\
\text { Marginal effects }\end{array}$ & $\begin{array}{l}-0.374(-0.84) \\
-0.037(-0.89)\end{array}$ & $\begin{array}{l}-0.519(-1.22) \\
-0.070(-1.36)\end{array}$ & $\begin{array}{l}-0.267(-0.79) \\
-0.078(-1.00)\end{array}$ & $\begin{array}{l}-0.151(-0.85) \\
-0.041(-1.18)\end{array}$ & $\begin{array}{l}-0.528(-0.69) \\
-0.068(-0.71)\end{array}$ & $\begin{array}{l}-0.448(-1.13) \\
-0.059(-1.27)\end{array}$ & $\begin{array}{l}-0.318(-0.97) \\
-0.044(-1.14)\end{array}$ & $\begin{array}{l}-0.446(-1.08) \\
-0.055(-1.13)\end{array}$ & $\begin{array}{l}-0.383(-0.87) \\
-0.031(-0.99)\end{array}$ & $\begin{array}{l}-0.532(-1.00) \\
-0.056(-1.19)\end{array}$ \\
\hline \multicolumn{11}{|l|}{ AUDIT $_{i, t-1}$} \\
\hline Coefficient estimates & $0.202 * *(1.98)$ & $0.125 *(1.87)$ & $0.103 *(1.79)$ & $0.126 *(1.86)$ & $0.109 *(1.75)$ & $0.185 *(1.84)$ & $0.249 * *(2.19)$ & $0.101 *(1.69)$ & $0.145 *(1.74)$ & $0.166 *(1.80)$ \\
\hline Marginal effects & $0.041 * *(2.17)$ & $0.018 *(1.94)$ & $0.014 *(1.85)$ & $0.033 *(1.92)$ & $0.019 *(1.81)$ & $0.036 *(1.91)$ & $0.045 * *(2.30)$ & $0.021 *(1.77)$ & $0.015 *(1.80)$ & $0.025 *(1.93)$ \\
\hline \multicolumn{11}{|l|}{$\begin{array}{l}\text { Control variables } \\
\text { ROA }\end{array}$} \\
\hline Coefficient estimates & & & $3.279 * * *(2.98)$ & $9.034 * * *(3.72)$ & $9.478 * * *(3.41)$ & $10.208^{* * * *(4.53)}$ & $13.590 * * *(3.15)$ & $6.119 * * *(3.24)$ & $3.238^{* * *}(3.45)$ & $10.501 * * *(5.60)$ \\
\hline \multicolumn{11}{|l|}{ LEVERAGE $_{i t+1}$} \\
\hline Coefficient estimates & $-1.578^{* * *}(-3.23)$ & $-3.545 * * *(-4.67)$ & & & $-3.977 * *(-2.43)$ & $-1.714 * *(-2.05)$ & $-2.334 * * *(-3.10)$ & $-3.053^{* * *}(-4.05)$ & $-2.717 * *(-2.07)$ & $-3.379 * *(-2.23)$ \\
\hline \multicolumn{11}{|l|}{ GROWTH $_{i t-1}$} \\
\hline Coefficient estimates & $-0.374 * *(-2.09)$ & $-0.631 * *(-2.34)$ & $-0.872 * *(-2.52)$ & $-0.246 *(-2.17)$ & & & $-0.196 * *(-2.29)$ & $-0.475 * * *(-2.82)$ & $-0.493 * *(-2.18)$ & $-0.314 * *(-2.00)$ \\
\hline $\begin{array}{l}\text { Marginal effects } \\
\text { FIRMSIZE }\end{array}$ & $-0.237 * *(-2.36)$ & $-0.311 * *(-2.45)$ & $-0.446 * *(-2.57)$ & $-0.138 * *(-2.25)$ & & & $-0.116^{* *}(-2.47)$ & $-0.217^{* * *}(-3.07)$ & $-0.189^{* *}(-2.32)$ & $-0.122 * *(-2.14)$ \\
\hline Coefficient estimates & $1.984 * * *(6.95)$ & $1.615 * * *(5.08)$ & $1.519 * * *(4.70)$ & $1.926 * * *(5.77)$ & $0.682 * * *(3.08)$ & $1.473 * * *(4.84)$ & & & $0.849 * * *(4.33)$ & $0.965 * * *(6.05)$ \\
\hline Marginal effects & $0.365 * * *(5.78)$ & $0.267^{* * * *}(4.50)$ & $0.207^{* * * *}(4.42)$ & $0.249^{* * * *}(5.35)$ & $0.189 * * *(2.96)$ & $0.342 * * *(4.67)$ & & & $0.141 * * *(4.05)$ & $0.258 * * *(5.32)$ \\
\hline \multicolumn{11}{|l|}{ BLOCKOWN } \\
\hline Coefficient estimates & $-0.836 * *(-2.25)$ & $-0.913 * *(-2.32)$ & $-1.746^{* *}(-2.07)$ & $-0.741 * *(-1.98)$ & $-1.029 * *(-2.37)$ & $-0.691 * *(-2.17)$ & $-0.675^{* *}(-2.22)$ & $-1.005 * *(-2.44)$ & & \\
\hline Marginal effects & $-0.136^{* *}(-2.44)$ & $-0.201 * *(-2.50)$ & $-0.261 * *(-2.29)$ & $-0.147 * *(-2.10)$ & $-0.197 * *(-2.48)$ & $-0.112^{* *}(-2.23)$ & $-0.149 * *(-2.38)$ & $-0.206 * *(-2.56)$ & & \\
\hline INDUSTRY & Yes & Yes & Yes & Yes & Yes & Yes & Yes & Yes & Yes & Yes \\
\hline YEAR & Yes & Yes & Yes & Yes & Yes & Yes & Yes & Yes & Yes & Yes \\
\hline \multicolumn{11}{|l|}{ Constant } \\
\hline Coefficient estimates & $-5.751^{* * *}(-3.19)$ & $-9.307^{* * *}(-8.40)$ & $-11.105^{* * *}(-7.42)$ & $-4.093 * *(-4.10)$ & $-9.876^{* * *}(-4.35)$ & $-5.362 * * *(-2.97)$ & $-5.896 * * *(-3.73)$ & $-10.055^{* * *}(-6.46)$ & $-10.688^{* * * *}(-5.10)$ & $-7.834 * * *(-4.49)$ \\
\hline Number of observations & 315 & 450 & 385 & 380 & 545 & 220 & 330 & 435 & 214 & 551 \\
\hline Wald $\chi^{2}$ & $21.92 * * *$ & $33.35^{* * * *}$ & $29.51 * * *$ & $40.23 * * *$ & $59.41 * * *$ & $39.37 * * *$ & $31.67 * * *$ & $26.98 * * *$ & $27.55^{* * * *}$ & $58.82 * * *$ \\
\hline$\rho$ value & 0.778 & 0.661 & 0.742 & 0.640 & 0.657 & 0.812 & 0.716 & 0.728 & 0.695 & 0.634 \\
\hline Likelihood ratio test & $75.06^{* * * *}$ & $52.90^{* * * *}$ & $52.78 * * *$ & $50.23 * * * *$ & $72.69 * * * *$ & $49.49 * * *$ & $60.13 * * *$ & $68.90 * * *$ & $48.08 * * *$ & $63.69 * * *$ \\
\hline
\end{tabular}

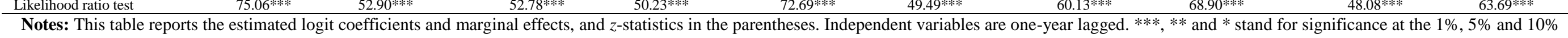
levels, respectively. 
Table 5. Results of Random Effects Tobit Model Estimates by Firm Characteristics

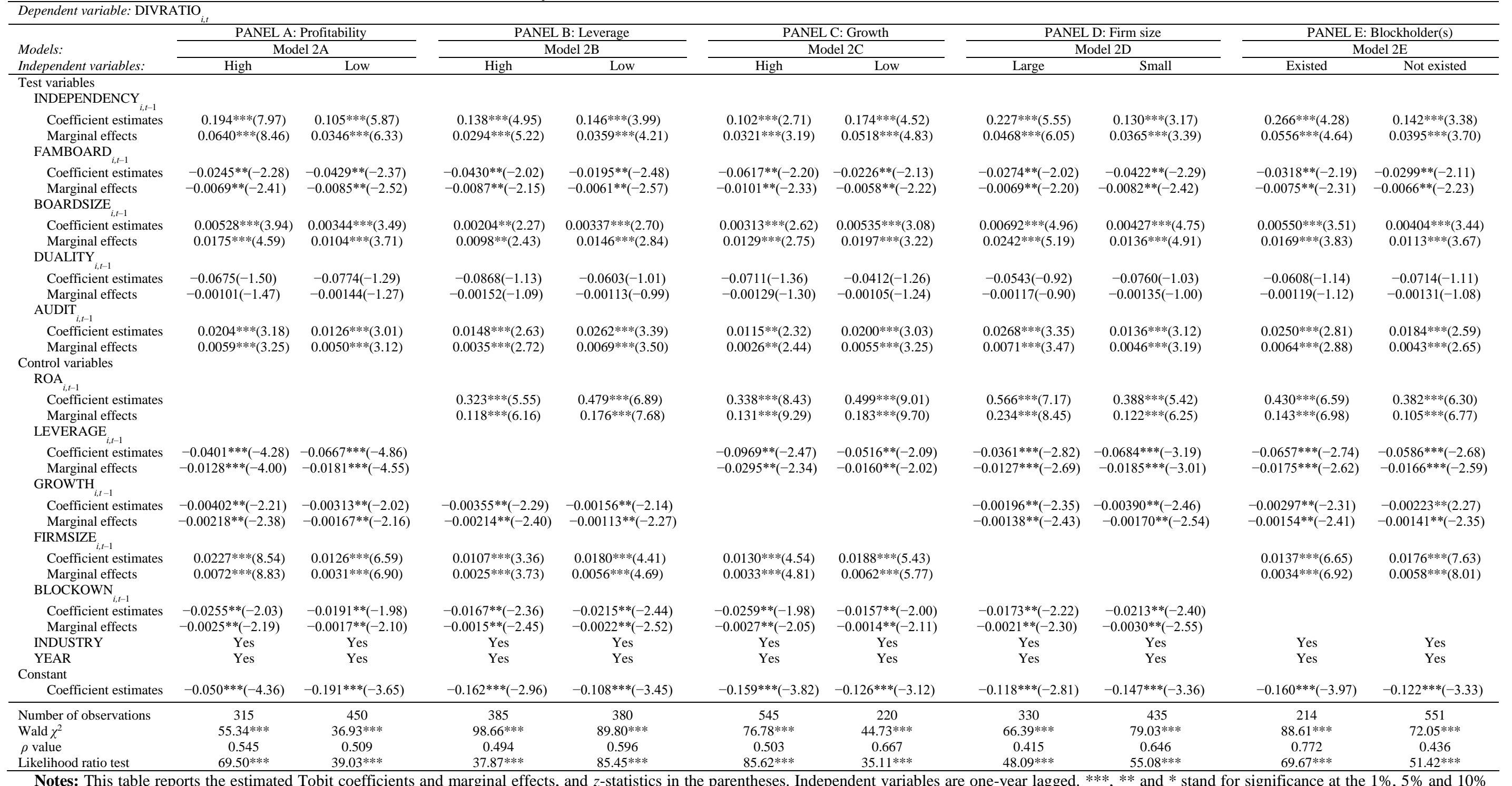

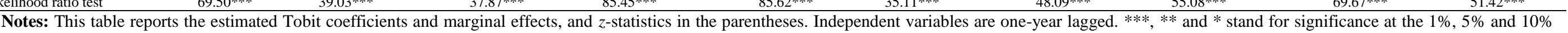
levels, respectively. 